\title{
Tephra clean-up after the 2015 eruption of Calbuco volcano, Chile: a quantitative geospatial assessment in four communities
}

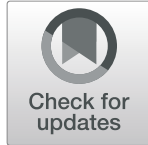

\author{
Josh L. Hayes ${ }^{1 *}$ (D), Thomas M. Wilson ${ }^{1}$, Carol Stewart ${ }^{2}$, Gustavo Villarosa ${ }^{3,4}$, Pablo Salgado ${ }^{3}$, Débora Beigt ${ }^{3}$, \\ Valeria Outes ${ }^{3}$, Natalia I. Deligne ${ }^{5}$ and Graham S. Leonard ${ }^{5}$
}

\begin{abstract}
Reliable methods for volcanic impact and risk assessments are essential. They provide constructive information to emergency and disaster managers, critical infrastructure providers, the insurance industry, and wider society. Posteruption clean-up of tephra deposits is a prevalent and expensive (time and resource) activity which is often not planned for. Here, we present an overview of the clean-up efforts undertaken in four communities after the VEI 4 eruption of Calbuco volcano in 2015. We narratively reconstruct clean-up efforts in Ensenada (Chile), Junín de los Andes (Argentina), San Martín de los Andes (Argentina), and Villa La Angostura (Argentina) using semi-structured interviews, syn- and post-deposition photographs, pre- and post-event visual spectrum satellite imagery, and media reports. We compare these reconstructions with estimates based on a geospatial modelling approach adapted from Hayes et al. (Journal of Applied Volcanology 6:1; 2017). Specifically, we compare reported and geospatially derived estimates for volume of tephra removed, and clean-up operation duration. Our modelling approach performed well for Junín de los Andes but did not adequately capture volume and clean-up operation duration for the three remaining case study locations. We discuss several sources of uncertainty (including observational errors and natural variance of tephra deposit thickness), reported tephra removal volume estimates, clean-up methods, land use, and temporal evolution of clean-up operation demand. Our work demonstrates the utility of using simple geospatial data to develop assessments for tephra clean-up for use in response and recovery planning, and quantitative volcanic impact and risk assessments.
\end{abstract}

Keywords: Volcanic ash, Volcanic hazard, Disaster recovery, Disaster waste management, Disaster risk management

\section{Background}

Widespread tephra fallout from explosive volcanic eruptions can damage the built environment (Blong 1984; Jenkins et al. 2014; Spence et al. 2005), cause infrastructure service disruption (Blong 1984; Wilson et al. 2012, 2014), and generate public and environmental health issues (Horwell and Baxter 2006). These effects can lead to compounding consequences that severely disrupt social and economic activities (Sword-Daniels et al. 2014). Attempting to foresee potential impacts and provide useful information to emergency managers, critical infrastructure providers, insurance industry, and wider

\footnotetext{
*Correspondence: josh.hayes911@gmail.com

'Department of Geological Sciences, University of Canterbury, Private Bag 4800, Christchurch 8140, New Zealand

Full list of author information is available at the end of the article
}

society is a critical component of best-practice volcanic risk reduction (Aspinall and Blong 2015; Baxter et al. 2008; Deligne et al. 2017a; Loughlin et al. 2015; Magill et al. 2006; Marzocchi and Woo 2009; McDonald et al. 2017; Sparks et al. 2013; Woo 2008). One of the primary methods of developing this information is to use hazard, exposure, and vulnerability data to conduct impact and risk assessments (e.g. Biass et al. 2012; Deligne et al. 2017a; Lirer and Vitelli 1998; Magill and Blong 2005). Most assessments to date have concentrated on quantifying potential life safety risks (Newhall 1982; Deligne et al. 2018) and damage to the built environment (Zuccaro et al. 2008; Deligne et al. 2017b). However, the disruption caused by tephra fall is often the major concern of stakeholders and removing tephra 
from the urban environment as part of clean-up operations is the typical response and recovery activity (Blong 1984; Durand et al. 2001; Hayes et al. 2015; Wilson et al. 2012). Relatively few assessments have quantitatively considered clean-up requirements, which limits the usefulness of these assessments for end-users, particularly if they have little or no experience managing tephra hazard (Hayes et al. 2015).

Existing assessments quantifying clean-up requirements after volcanic eruptions have focussed on using geospatial modelling approaches to assess the potential volume (or mass) of tephra requiring removal, and the associated costs of clean-up operations (e.g. Biass et al. 2017; Johnston et al. 2001; Hayes et al. 2017; Magill et al. 2006; Zuccaro et al. 2013). Hayes et al. (2017) also attempted to model durations of clean-up operations under different eruption scenarios. Each of the above assessments contain useful information to communicate tephra clean-up requirements to stakeholders. However, there have been limited efforts to retrospectively evaluate how accurate estimates produced by these approaches are with respect to real events. This may be partially due to the limited opportunities to obtain the necessary data (Wilson et al. 2012, 2014). Model validation is undertaken in diverse hazard and risk assessment fields to verify that models are accurate and consistent with their intended purpose (e.g. vulnerability indices: Bakkensen et al. 2016; predictive hazard and risk models: Beguería 2006; predictive landslide hazard models: Chung and Fabrri 2003; tsunami vulnerability models: Dominey-Howes and Papathoma 2007; influenza contamination: Fisher et al. 2014; power outage duration models: Nateghi et al. 2011; hurricane loss models: Watson Jr and Johnson 2004). Craig et al. (2016) used data from the 2011 Cordón Caulle eruption to evaluate several published tephra damage and disruption states, including tephra clean-up operation threshold indicators from Hayes et al. (2015). These semi-quantitative threshold indicators predicted clean-up operations relatively well (Craig et al. 2016). Here we build upon the work of Hayes et al. (2015) and Craig et al. (2016) to test an empirically inspired tephra clean-up model on an independent case study.

In this paper we quantitatively assess tephra clean-up operation models using data from semi-structured interviews, official governmental reports, pre- and postdeposition photographs, and visual spectrum satellite imagery from four communities in Chile and Argentina following the 2015 eruption of Calbuco Volcano. Our objectives are to:

- Assess clean-up requirements at different distances from the vent and in diverse climatic settings following the Calbuco 2015 eruption. We examine four communities: Ensenada, Chile; Villa La Angostura (VLA), Argentina; San Martín de los Andes (SMA), Argentina; and Junín de los Andes (JDA), Argentina (Fig. 1);

- Retrospectively apply the Hayes et al. (2017) conceptual clean-up model based on field data (e.g. volume of tephra removed, number and size of dump trucks used); and

- Evaluate the effectiveness of the Hayes et al. (2017) conceptual modelling approach to estimate clean-up requirements in each of the four selected communities.

\section{Data collection}

To collect the required information, we conducted semi-structured interviews with officials from organisations involved with the response to the eruption and residents affected by the eruption in both Chile and Argentina. Interviews were conducted as part of a larger research project assessing the impacts from the Calbuco 2015 eruption on infrastructure, facilities, primary industries, and public health (see Hayes et al. 2019a). The project was reviewed and approved by the University of Canterbury Human Ethics Committee (Ref: HEC 2016/69/LR-PS). The majority of interviews were conducted in November-December 2016, 19 months after the eruption: this allowed sufficient time for those involved to reflect on their experience (Craig et al. 2016; Magill et al. 2013; Wantim et al. 2018; Wilson et al. 2011). Interviews were conducted in Spanish and translated by research team members fluent in both Spanish and English. Specific information we sought from interviewees included: the volume of tephra removed during clean-up operations, the quantity of different resources utilised for clean-up (e.g. dump trucks, heavy earth-moving machinery, labourers), location of disposal sites, duration of clean-up operations, and challenges associated with cleaning up. Interview notes were compiled and analysed to identify common themes. We supplement semi-structured interview data with official reports, photos, satellite imagery, and, where appropriate, local media reports. We make it clear throughout the text when these supplementary data sources are used.

\section{The 2015 eruption of Calbuco volcano}

Calbuco volcano is in the southern Andes of Chile (Fig. 1). The volcano is located about $30 \mathrm{~km} \mathrm{NE}$ of Puerto Montt and $30 \mathrm{~km} \mathrm{E}$ of Puerto Varas. There have been at least 12 historical eruptions at Calbuco over the last 226 years of Volcanic Explosivity Index (VEI) (Newhall and Self 1982) 2-4 (Global Volcanism Program (GVM) 2013). On April 22, 2015 Calbuco volcano erupted with little to no detected indication of an imminent eruption from monitoring equipment 


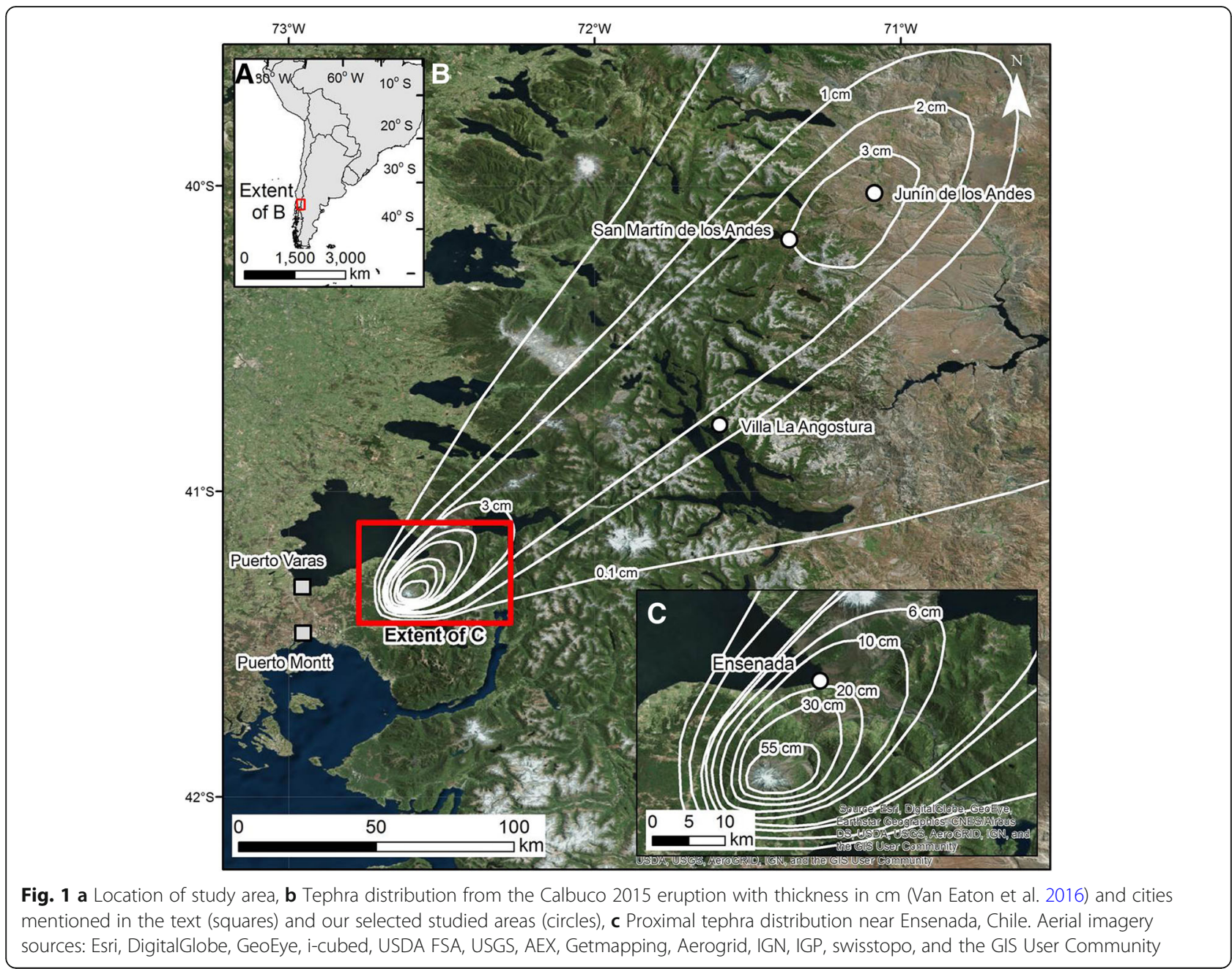

(Valderrama et al. 2016). The sub-Plinian VEI 4 eruption comprised three main eruptive pulses and dispersed tephra in a predominantly NE direction (Fig. 1; Van Eaton et al. 2016). The bulk erupted volume of the eruption is estimated as $0.56 \pm 0.28 \mathrm{~km}^{3}$ (Van Eaton et al. 2016). Tephra characteristics in each of the four case study communities are shown in Table 1.

\section{Clean-up in study communities}

In this section we discuss the clean-up response for each community, in order of increasing distance from the volcano. Where possible we quantify the clean-up resources required, the duration of the clean-up operation, and volumes of tephra removed.

\section{Ensenada, Chile}

Ensenada is a sparsely populated rural settlement situated $10-15 \mathrm{~km}$ NE of Calbuco volcano. It is serviced by one major road, Route 225 (Fig. 2). Most residents live in smaller settlements within Ensenada along Route 225; narrow local gravel roads off Route 225 lead to farms. The permanent population of Ensenada is approximately 4000, but during the tourism season (December-February) it can increase to over 10,000. Ensenada was evacuated when Calbuco erupted in April 2015 (Hayes et al. 2019a). Route 225 was affected by up to $20 \mathrm{~cm}$ of tephra from the eruption, which was only accessible by 4WD vehicles (Hayes et al. 2019a). Consequently, a priority of the emergency response was to restore road connectivity between Puerto Varas and Ensenada for evacuation purposes (Hayes et al. 2019a). Prior to this eruption, there were no plans for tephra clean-up operations, but the Oficina Nacional de Emergencia del Ministerio del Interior (National Emergency Office of the Ministry of the Interior, ONEMI) had support agreements with contractors to help mobilise heavy machinery during emergencies (Hayes et al. 2019a). Road clean-up was coordinated by the Los Lagos Dirección de Vialidad (roads department) within the Ministerio de Obras Públicas (Ministry of Public Works) (MOP), and the Municipality of Puerto Varas contributed to these 
Table 1 Climatic and tephra characteristics of each case study (Peel et al. 2007; Reckziegel et al. 2016; Villarosa et al. 2016; Romero et al. 2016; van Eaton et al. 2016). CfB and CsB are codes within the Köppen-Geiger climate classification system

\begin{tabular}{|c|c|c|c|c|}
\hline Characteristic & Ensenada, Chile & $\begin{array}{l}\text { Villa La Angostura, } \\
\text { Argentina }\end{array}$ & $\begin{array}{l}\text { San Martín de los } \\
\text { Andes, Argentina }\end{array}$ & $\begin{array}{l}\text { Junín de los } \\
\text { Andes, Argentina }\end{array}$ \\
\hline $\begin{array}{l}\text { Köppen-Geiger } \\
\text { climate classification }\end{array}$ & $\begin{array}{l}\text { CfB: Warm summers } \\
\text { and no dry season }\end{array}$ & $\begin{array}{l}\text { CfB: Warm summers } \\
\text { and no dry season }\end{array}$ & $\begin{array}{l}\text { CsB: dry and } \\
\text { warm summers }\end{array}$ & $\begin{array}{l}\text { CsB: dry and } \\
\text { warm summers }\end{array}$ \\
\hline $\begin{array}{l}\text { Distance from } \\
\text { Calbuco }(\mathrm{km})\end{array}$ & 13 & 100 & 170 & 200 \\
\hline $\begin{array}{l}\text { Measured tephra } \\
\text { thickness }(\mathrm{cm})\end{array}$ & $\begin{array}{l}11-17 \text { near village centre, } \\
1-35 \text { in surrounding } \\
\text { inhabited areas }\end{array}$ & $0.2-0.3$ & $0.5-3$ & $0.9-3+$ \\
\hline $\begin{array}{l}\text { Isopach thickness } \\
\text { (cm, interpolated } \\
\text { from Fig. 1) }\end{array}$ & $\begin{array}{l}10-20 \text { near village centre, } \\
0.1-55 \text { in surrounding } \\
\text { inhabited areas }\end{array}$ & $1-2$ & $2-3$ & $3+$ \\
\hline Grain size $\varphi$ & $\begin{array}{l}\text { Polymodal, identified } \\
\text { modes: - } 2 \text { (4 mm), } \\
-1(2 \mathrm{~mm}), 0(1 \mathrm{~mm})\end{array}$ & $\begin{array}{l}\text { Bimodal, } \\
\text { identified modes: } \\
3(0.1 \mathrm{~mm}), 5(0.02 \mathrm{~mm})\end{array}$ & $\begin{array}{l}\text { Bimodal, } \\
\text { identified modes: } \\
4(0.06 \mathrm{~mm}), 5(0.02)\end{array}$ & $\begin{array}{l}\text { Bimodal, } \\
\text { identified modes: } 4 \\
(0.06 \mathrm{~mm}), 5(0.02 \mathrm{~mm})\end{array}$ \\
\hline
\end{tabular}

operations by mobilising road graders. To clear and reopen the road between Ensenada and Puerto Varas to the west and Puerto Octay to the north, graders were used to push the bulk of the tephra to the sides of the road (Fig. 3a). Grading of the roads to a driveable standard was complete within 1-2 days. Approximately 50 heavy machines (including bobcats, diggers and loaders) were then used to load tephra into 60 six-wheeler dump trucks, which transported tephra to an initial staging site before final transport to several permanent disposal sites in the region (Hayes et al. 2019a). Once the bulk of the tephra had been removed, road brooming using two street sweepers and washing using eight water trucks was undertaken to remove the fine tephra residue remaining. It took approximately 1 month to clear the majority of the tephra from roads around the volcano, although some small local gravel roads still had tephra on them in December 2016 (Hayes et al. 2019a).

Most private residential properties in Ensenada are located along Route 225 or in the communities of Los Álamos, Los Volcanes, El Zorro, and Los Arrayanes (Fig. 2). These communities were within the evacuation zone established by ONEMI in response to the 2015 eruption. Evacuated property owners were concerned about heavy rain forecasted for the days following the eruption, as they feared that it would increase the weight of tephra on roofs and exacerbate building damage (Hayes et al. 2019b). These concerns led authorities to allow a controlled daytime return of residents into Ensenada to clean their properties, but only between 8 a.m. - 5 p.m. Over 1000 military personnel and volunteers helped clean-up properties. Cleaning of residential properties began by sweeping tephra from building roofs into piles on the ground. Tephra was then shovelled into wheelbarrows and dumped at the roadside for bulk collection using heavy machinery. One person was hospitalised during clean-up activities after falling through a skylight obscured by tephra whilst cleaning a roof (Hayes et al. 2019a). On 31 April 2015, a third eruptive pulse occurred whilst clean-up was being conducted, forcing an immediate evacuation of the area. Clean-up of most private properties was complete within 6 months. However, due to a high rate of absentee owners of holiday homes, in December 2016 the Dirección de Vialidad was still fielding calls to pick up tephra that had been dumped on the road side and substantial amounts of tephra were observed on fields in the area.

Over $300,000 \mathrm{~m}^{3}$ of tephra was collected and disposed of, mostly on private land of volunteers willing to accept the tephra to fill in topographic depressions (Fig. 3e \& f). No stabilisation efforts to reduce potential wind or water remobilisation were undertaken at disposal sites as the tephra fall deposit was deemed sufficiently coarse (see Table 1) (Hayes et al. 2019a). The tephra deposit naturally revegetated. We note areas previously affected by previous large tephra falls in Chile such as Hudson in 1991 and Chaitén in 2008 suffered ongoing remobilisation issues, particularly for fine grained deposits in arid environments (Hayes et al. 2015, 2019a; Wilson et al. 2011). Los Lagos has a temperate climate with an average annual rainfall rate of $1942 \mathrm{~mm}$ (ClimateData.org 2019), but we do not know if this aided clean-up activities by suppressing windblown remobilisation or washing the tephra away.

The total cost for the road clean-up coordinated by MOP was estimated at US\$1.3 million (2015 value; we report in 2015 US\$ throughout this paper). Approximately $80 \%$ of this was for machinery hire, maintenance, contractors, and fuel. The remainder was for health/ safety/hygiene, information/communication, and office materials. An existing agreement with contractors to provide assistance during emergencies ensured the cost 


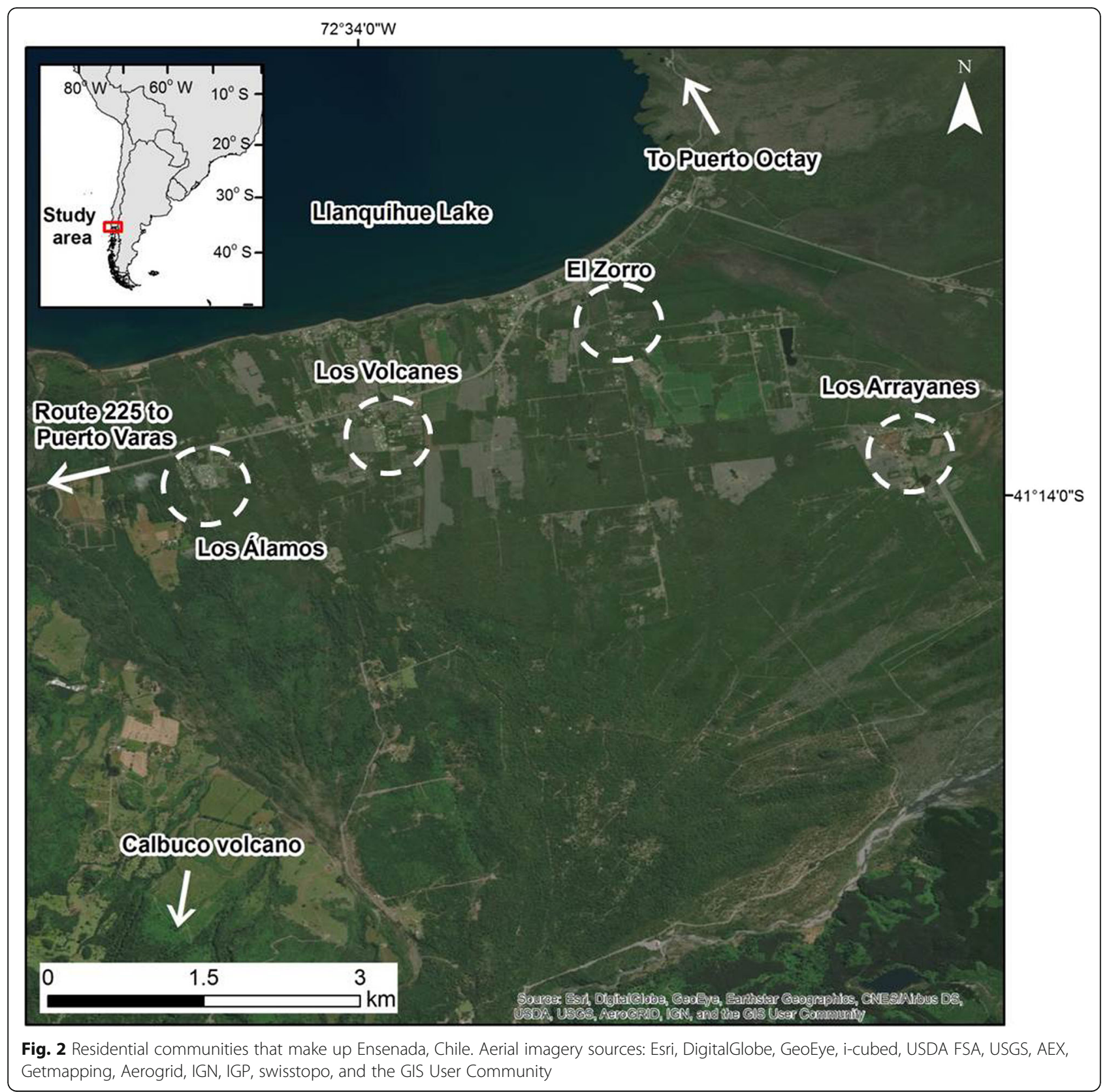

of road clean-up was set at a fixed rate. These contracts are negotiated every 4 years and MOP credited them for keeping costs relatively static across each four-year period.

Clean-up of private properties and farms was expensive for the property owners. A study by the Chilean military estimated that the cost of removal of tephra from agricultural land would be on the order of 1.8 million Chilean pesos (US\$2880) per hectare, an estimate considered to be prohibitively high for many of the local farmers (Hayes et al. 2019a). As a result, substantial volumes of tephra deposited on agricultural land were not removed and as of December 2016, many farms had not recommenced agricultural activities in the area (Hayes et al. 2019a). We do not have any data estimating the loss of earnings due to the eruption. The Chilean Ministerio de Agricultura (MINAGRI) expected that agricultural activities would be precluded on farms affected by over $15 \mathrm{~cm}$ of tephra in the immediate future due to these substantial removal costs (Hayes et al. 2019a). However, to rehabilitate the land some (an unknown proportion) farmers removed the top $30-50 \%$ of tephra and then ploughed and mixed the remaining tephra into the 

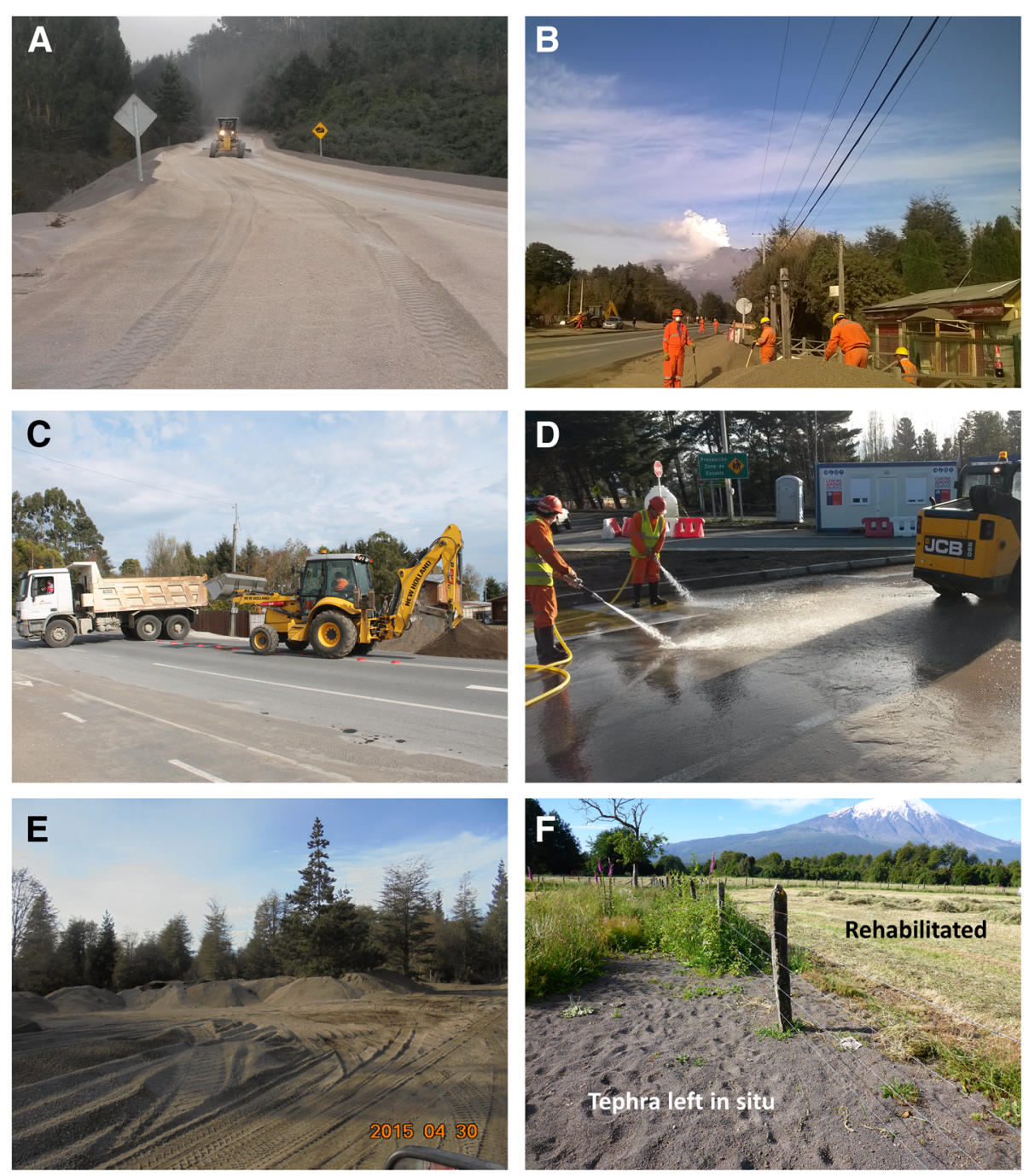

Fig. 3 Clean-up in Ensenada, Chile. a Grader moving tephra from centre of road (photo: MOP, Date: 24 April, 2015), b workers removing tephra from properties and placing in piles at roadside (photo: MOP, Date: 30 April, 2015) c bulk removal of tephra using heavy machinery and dump trucks (photo: MOP, Date: 22 September, 2015), d washing roads of fine tephra residue (photo: MOP, Date: 11 June, 2015), e a tephra disposal site (photo: MOP, Date: 30 April, 2015), f rehabilitated farm land affected by $20 \mathrm{~cm}$ of tephra (Date: 2 December, 2016)

underlying soil with promising results (Hayes et al. 2019a; Fig. 3f).

\section{Villa La Angostura, Argentina}

Villa La Angostura (VLA) is a tourist town with a permanent population of $\sim 12,000$ (Ministerio del Interior 2018a), located $100 \mathrm{~km}$ from Calbuco volcano in the Neuquén province of Argentina. It is situated within a temperate climate zone at the northern end of Lago Nahuel Huapi. Its economy is based on tourism and the town has strong seasonal increases in population due to influxes of tourists (Craig et al. 2016).

Tephra deposition on the town from the 2015 Calbuco eruption was measured to be $0.2 \mathrm{~cm}$ (Reckziegel et al. 2016). Van Eaton et al. (2016) supporting information includes measurements on the outskirts of VLA taken on 29 April 2015 of $2 \mathrm{~cm}$ thick, although co-authors of this work were unable to find thicknesses exceeding $1 \mathrm{~cm}$ near VLA in the days immediately following the eruption. Despite being closer to the vent than San Martín de los Andes (SMA) or Junín de los Andes (JDA), VLA received less tephra fall as it lay off the principle axis of dispersion (Fig. 1). The clean-up for Calbuco 2015 tephra fall was reportedly much easier than the clean-up following the deposition of $20 \mathrm{~cm}$ of tephra from the Cordón Caulle eruption in June 2011 (Elissondo et al. 2016; Craig et al. 2016; Wilson et al. 2013), mostly due to the much smaller accumulation of tephra. The recent experience of the 2011 Cordón Caulle tephra fall had taught the community what to do during and following a tephra fall. In 2015, tephra was collected and piled from 
private, commercial, and public properties using manual labour (e.g. brooms, shovels, wheelbarrows) and then loaded onto dump trucks using heavy earth-moving machinery before being transported to dump sites. Dump sites were already established from the 2011 event. There were only six road crews (trucks and heavy machinery) assigned to cleanup VLA, and all operations were conducted with existing staff (Gobierno de la Provincia del Neuquen 2015d). Even with relatively limited resources, clean-up was mostly complete within one and a half weeks (Gobierno de la Provincia del Neuquen 2015d), but washing of roads using pressurised water continued for a total of 20 days after initial tephra deposition to reduce remobilisation issues. Rainfall 1 week after the tephra fall event reportedly assisted the cleanup process by washing a small amount of fine tephra residue into the storm water system.

VLA has four disposal sites that were established for Cordón Caulle 2011 tephra and utilised for the Calbuco eruption. Sites include a mallín (low-lying floodplain or wetland) on Route 40 from VLA to SMA (disposal site A: surface area $\sim 6500 \mathrm{~m}^{2}$ ), a mallín along Siete Lagos Rd. (disposal site B: surface area $\sim 5400 \mathrm{~m}^{2}$ ), a back road beside the Rio Piedritas (disposal site C: surface area $\sim 4500$ $\mathrm{m}^{2}$ ), and an old quarry near Puerto Manzano (disposal site D: surface area $\sim 20,000 \mathrm{~m}^{2}$ ) (Fig. 4). Tephra that was dumped at disposal site B was about two metres thick (compacted) and allowed to revegetate naturally. However, most of the tephra disposed in each location was from the 2011 Cordón Caulle eruption; there is no data available on the amount of tephra from VLA that was disposed after the Calbuco eruption at each disposal location, possibly due to the very low volumes collected.

\section{San Martín de los Andes, Argentina}

San Martín de los Andes (SMA) is a city of $~ 30,000$ inhabitants located within the Neuquén province of Argentina approximately $170 \mathrm{~km}$ NE of Calbuco volcano (Ministerio del Interior 2018b). SMA lies along the principle axis of dispersion and was affected by up to $1 \mathrm{~cm}$ from the 2011 Cordón Caulle eruption (Alloway et al. 2015). The experience and lessons learned in 2011 were utilised for cleaning the tephra deposited during the 2015 Calbuco eruption. A key lesson from 2011 was to involve residents in the clean-up efforts early as this reduced the load on municipality resources. Measured tephra thickness from the 2015 Calbuco eruption of $0.5 \mathrm{~cm}$ in the centre of the SMA urban area was reported by Reckziegel et al. (2016). However, Van Eaton et al. (2016) supporting information includes estimated thicknesses of $2-3 \mathrm{~cm}$ made on 29 April 2015 at Route 40 approximately $500 \mathrm{~m}$ south of SMA. Police, fire, army personnel, and approximately 1000 volunteers helped with the clean-up of city streets and facilities (e.g. schools and airport). Schools were cleaned within 3 days, but it took 50 volunteers 10 days to complete the clean-up at Aviador Carlos Campos Airport. Fourteen road crews using dump trucks and snow ploughs were used to clean-up SMA streets (San Martín Diario 2015). Hospital, police/fire station areas, and health centres were prioritised for cleanup, and then bus service routes were cleaned to reduce remobilisation effects. Roads were cleaned using graders, diggers, and trucks, but were later re-contaminated when people dumped tephra from their properties at street corners for collection. This required a second cleaning of roads at the end of the clean-up operation. The downtown area took approximately 2 weeks to complete clean-up, and clean-up of the entire town took about 2 months.

During the interviews we conducted in Argentina, officials in SMA expressed that they considered the Calbuco 2015 tephra more problematic to clean-up, the reason for which they attributed to Calbuco tephra being more easily remobilised than the 2011 Cordón Caulle tephra. The Calbuco 2015 clean-up was also the first considerable clean-up required in SMA, as the Cordón Caulle tephra was very thin and discontinuous. SMA officials said that wet clean-up methods worked well for the Cordón Caulle tephra, which washed into the drainage system and into Lake Lacar. However, the Calbuco tephra become cementitious and clogged drains. This meant that suction machines were required to clear the drains, and shovels had to be used where substantial mixing of leaves and tephra occurred. As a consequence, the public were advised to stop using water for clean-up.

Clean-up began on 24 April 2015 and was conducted between the hours of $7 \mathrm{a} . \mathrm{m}$. and 2 p.m. each day. These hours were adopted to avoid overtime being charged to the municipality. By 5 May 2015 approximately $3000 \mathrm{~m}^{3}$ had been removed from SMA, an average of $200 \mathrm{~m}^{3}$ per day (Gobierno de la Provincia del Neuquen 2015a). Another estimate reported in the media on 11 May 2015 was $6000 \mathrm{~m}^{3}\left(300 \mathrm{~m}^{3}\right.$ per day) (RioNegro 2015). The final estimate reported by Gobierno de la Provincia del Nequen was $10,000 \mathrm{~m}^{3}$ on 14 May $2015\left(500 \mathrm{~m}^{3}\right.$ per day) (Gobierno de la Provincia del Neuquen 2015c). In total it was reported to us during interviews that 2500 truckloads (capacity of $\sim 5 \mathrm{~m}^{3}$ ) were required to remove the tephra from SMA. Assuming these trucks were at capacity, this yields a total clean-up volume of 12,500 $\mathrm{m}^{3}$ removed over the two-month long clean-up operation; an average tephra removal rate of $200 \mathrm{~m}^{3}$ per day. An unknown, but likely small, amount of tephra was left behind on gravel roads.

There were no pre-existing plans for disposal of tephra. Officials dumped the tephra near the lake (Fig. 5), but other locations (e.g. on military property) were utilised for smaller (but unmeasured) volumes of tephra. 


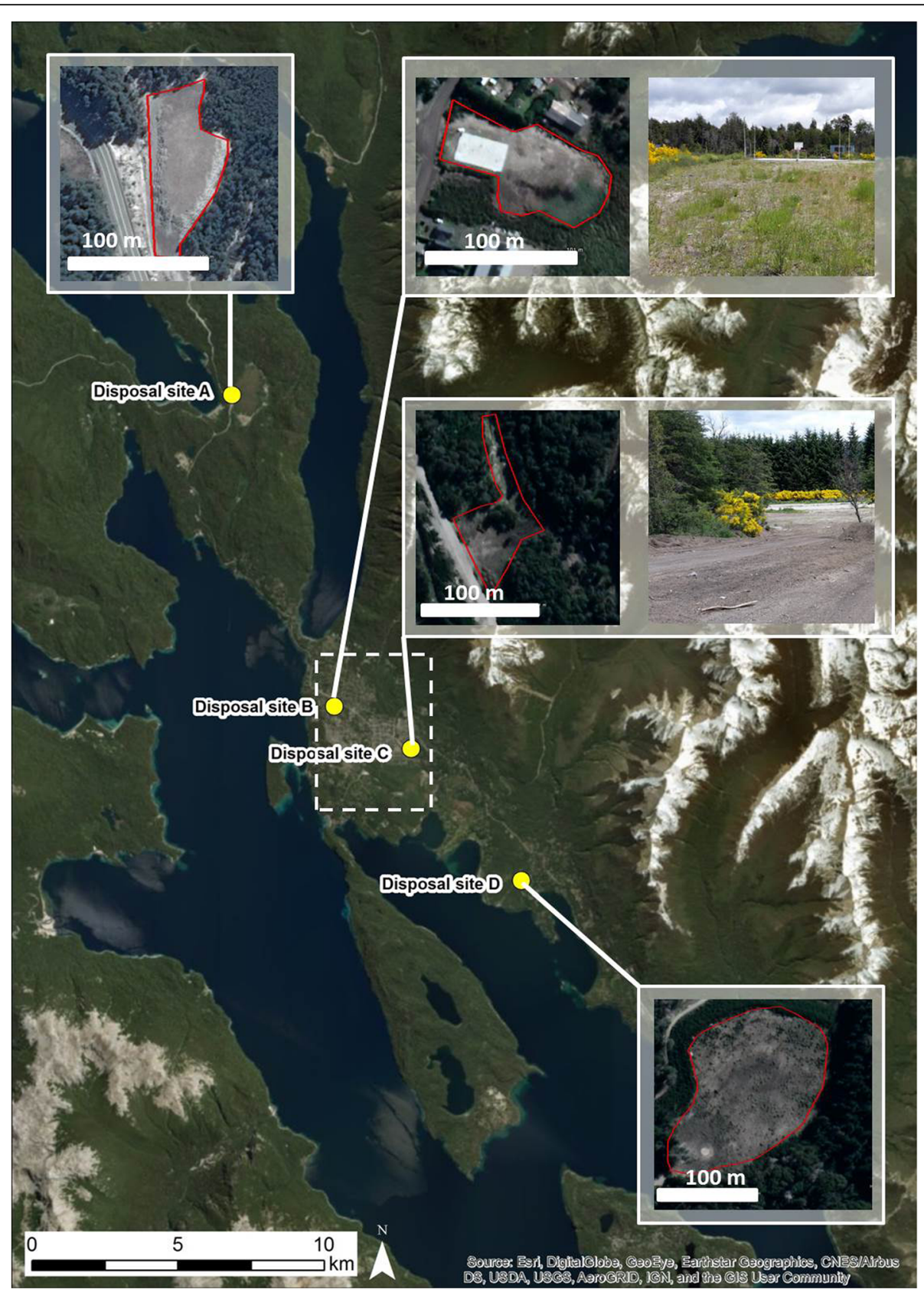

Fig. 4 Disposal sites used for tephra deposition in VLA. Aerial imagery sources: Esri, DigitalGlobe, GeoEye, i-cubed, USDA FSA, USGS, AEX Getmapping, Aerogrid, IGN, IGP, swisstopo, and the GIS User Community dated 26 March 2018. Ground photos from December 2016 (20 months post deposition). White dashed box is approximate extent of VLA

\section{Junín de los Andes, Argentina}

Junín de los Andes (JDA) is a small town of 15,000 inhabitants located about $200 \mathrm{~km} \mathrm{NE}$ of Calbuco volcano in the Neuquén province of Argentina (Ministerio del Interior 2018c). Its climate is distinctly more arid than that of SMA, despite being located only $30 \mathrm{~km}$ away (Fig. 1). Compared to SMA, JDA received more tephra fall (1.5 cm in Romero et al. (2016) to an estimated 3+ cm in Van Eaton et al. (2016) supporting material) due to a secondary thickening effect (Fig. 1). Tephra fall in JDA was very fine-grained (Reckziegel et al. 2016). As a consequence of the fine grainsize and the dry climate, tephra was easily remobilised by aeolian and anthropogenic processes (Fig. 6). To counteract this, attempts were made to keep the tephra permanently damp using watering trucks.

Clean-up of tephra from JDA began on 24 April 2015 (Gobieno de la Provincia del Neuquen 2015a). To 


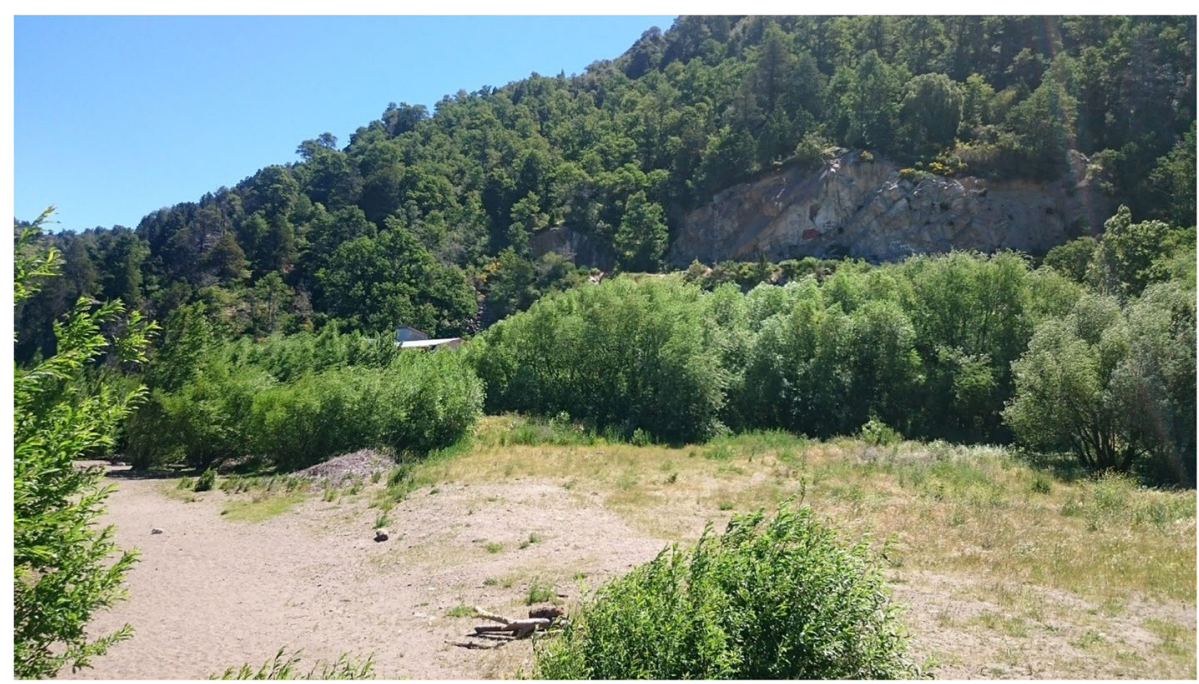

Fig. 5 Dump site near Lácar Lake for tephra from San Martín de los Andes (Photo: Daniel Blake, taken December 2016)

conduct clean-up, JDA was divided into five sectors, each with two sprinkler trucks, a motor grader, one or two loaders, and two dump trucks (Gobieno de la Provincia del Neuquen 2015a). However, 50 dump trucks were in operation when the clean-up was at its peak. The local volunteer fire brigade mobilised to help with the clean-up of properties and to remove tephra from roofs (Fig. 7). Dry brushing was mostly used to remove tephra from roofs. In some instances, water was used to remove tephra from roofs, but this led to the tephra becoming cemented and sticking to the surface.

By 29 April 2015, $5000 \mathrm{~m}^{3}$ of tephra had been removed from JDA and taken to the tephra dump, an average tephra removal rate of approximately $800 \mathrm{~m}^{3}$ per day (Gobierno de la Provincía del Neuquen 2015b). On 4 May 2015, the Undersecretary of Planning and Public Services reported that about $15,000 \mathrm{~m}^{3}$ of tephra had been removed (tephra removal rate of $1400 \mathrm{~m}^{3}$ per day) and forecast that about one more month of work was required to complete cleanup (Gobierno de la Provincia del Neuquen 2015a). As of 11
May 2015, the estimate was reported at $32,000 \mathrm{~m}^{3}\left(1800 \mathrm{~m}^{3}\right.$ per day) (RioNegro 2015), and it was estimated that approximately $40,000 \mathrm{~m}^{3}$ of tephra were removed in total from JDA as of 14 May 2015 (1900 $\mathrm{m}^{3}$ per day) (Gobierno de la Provincia del Neuquen 2015c).

A local garbage dump was used to dispose of the collected tephra (Fig. 8; Gobierno de la Provincia del Neuquen 2015a). Planned remediation for the site was to add a soil cap and vegetate to prevent remobilisation of the tephra, but this had not been completed as of April 2018.

\section{Methodology}

In the following subsections we outline our approach, adapted from Hayes et al. (2017), to model tephra removal volumes and clean-up durations.

\section{Removed tephra volume}

It is useful to forecast the amount of tephra to be removed when preparing for tephra clean-up operations,
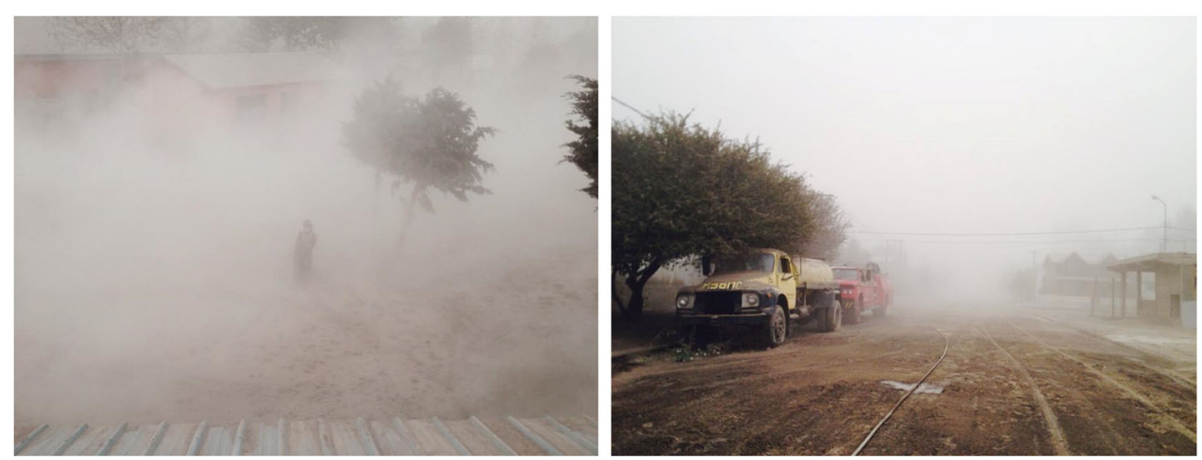

Fig. 6 Remobilisation of tephra in Junín de Los Andes in April 2015 (photos courtesy of Bomberos de Junín de Los Andes) 

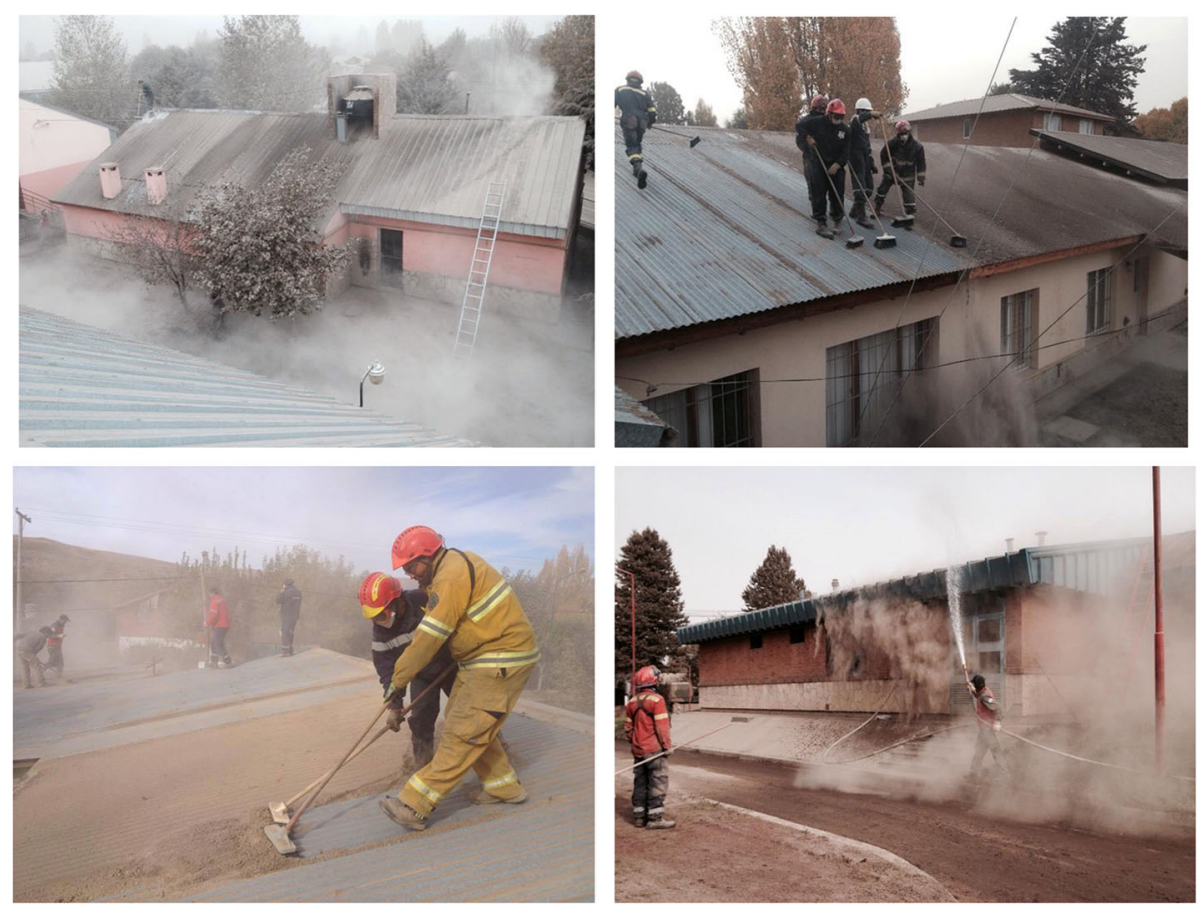

Fig. 7 Cleaning tephra from roofs in Junín de Los Andes (photos courtesy of Junín de Los Andes Bomberos, Date: April 2015)

as it provides emergency managers with information on relative effort required (e.g. resource requirements) and constraints on the potential disposal locations (Brown et al. 2011; Hayes et al. 2015). For example, to model the volume of tephra that may need to be removed from Auckland, New Zealand after a volcanic eruption, Hayes et al. (2017) assessed how much tephra would be deposited on different urban surfaces within the urban area. They used empirically informed, but largely theoretical, tephra thickness thresholds to define what urban surfaces would have tephra removed and taken to disposal sites. To apply the model in this study, we:

- define the spatial extent of our case study communities that requires clean-up;

- obtain data relating to the proportion of different urban surfaces within that spatial extent; and

- use measured and interpolated thickness data to calculate the volume of tephra requiring removal.

For VLA, JDA, and SMA, we use the extent of the built-up area to determine the spatial extent for sampling and digitising of urban surfaces (Fig. 9). Ensenada presents an additional challenge, as the extent of the built-up area is not obvious. Instead we use the areal extent of the 4 communities that make up Ensenada and the transport corridor that connects each of them.
High quality geospatial data of urban surfaces (e.g. impervious surfaces, building footprints) were unavailable for our analysis - a common issue for many communities exposed to tephra fall across the world. Open Street Map (OSM) is a freely editable and open source of geospatial data that is built by volunteers using aerial imagery and local knowledge. Open Street Map contains reasonable quality road lines, but in our study area the quality for building footprints is highly variable and does not contain useful information regarding other paved surfaces, such as sidewalks, driveways, and carparks. Digital Globe (satellite imagery company) imagery can be used to digitally map different urban surfaces, but without an automated approach this is time-consuming and labour-intensive. Thus, we digitised buildings and paved areas (excluding roads) in a representative sample area at each location and used this to estimate the proportional area in our study locations made up of road, building, and other impervious surfaces. To do this we constructed a $100 \times 100 \mathrm{~m}$ gridded area of the clean-up extent for each of our case study communities and randomly digitised impervious surfaces (except road) in the necessary number of grid cells to obtain $95 \%$ confidence level and standard error of 5\%. The dates of the imagery used were:

- Ensenada $=29$ November 2015

- JDA = 23 January 2013

- $\mathrm{SMA}=10$ October 2014

- VLA = 07 January 2015 


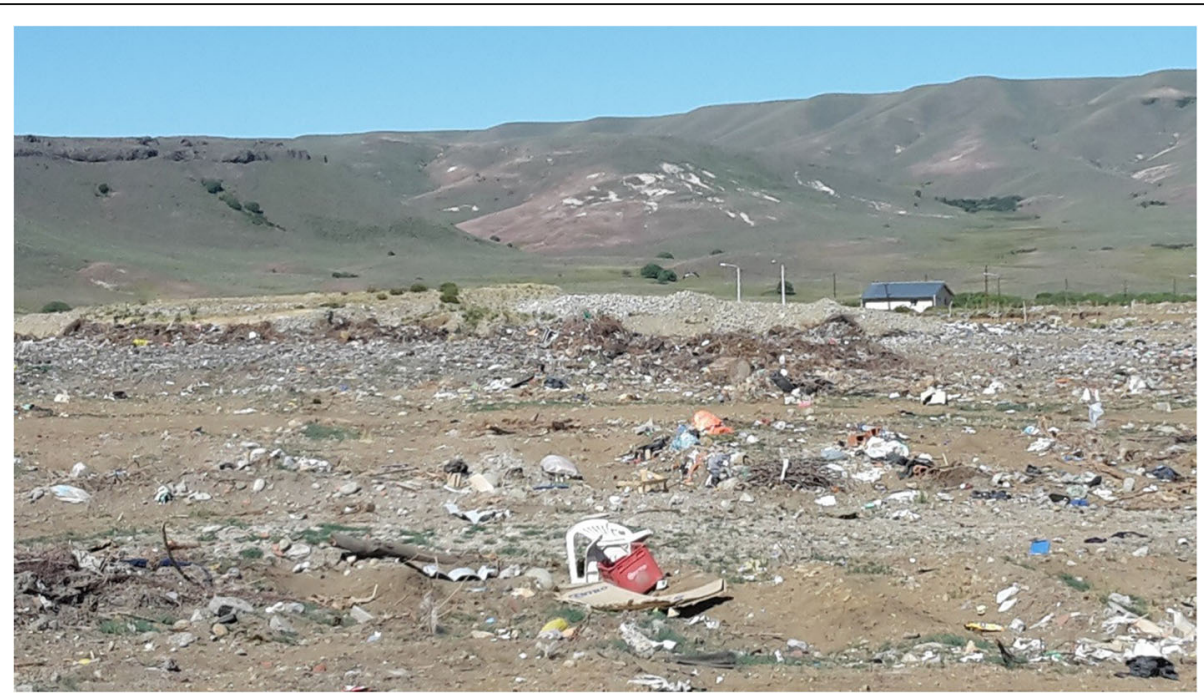

Fig. 8 Former garbage dump where Junín de los Andes tephra was dumped (Photo: Carol Stewart, December 2016)
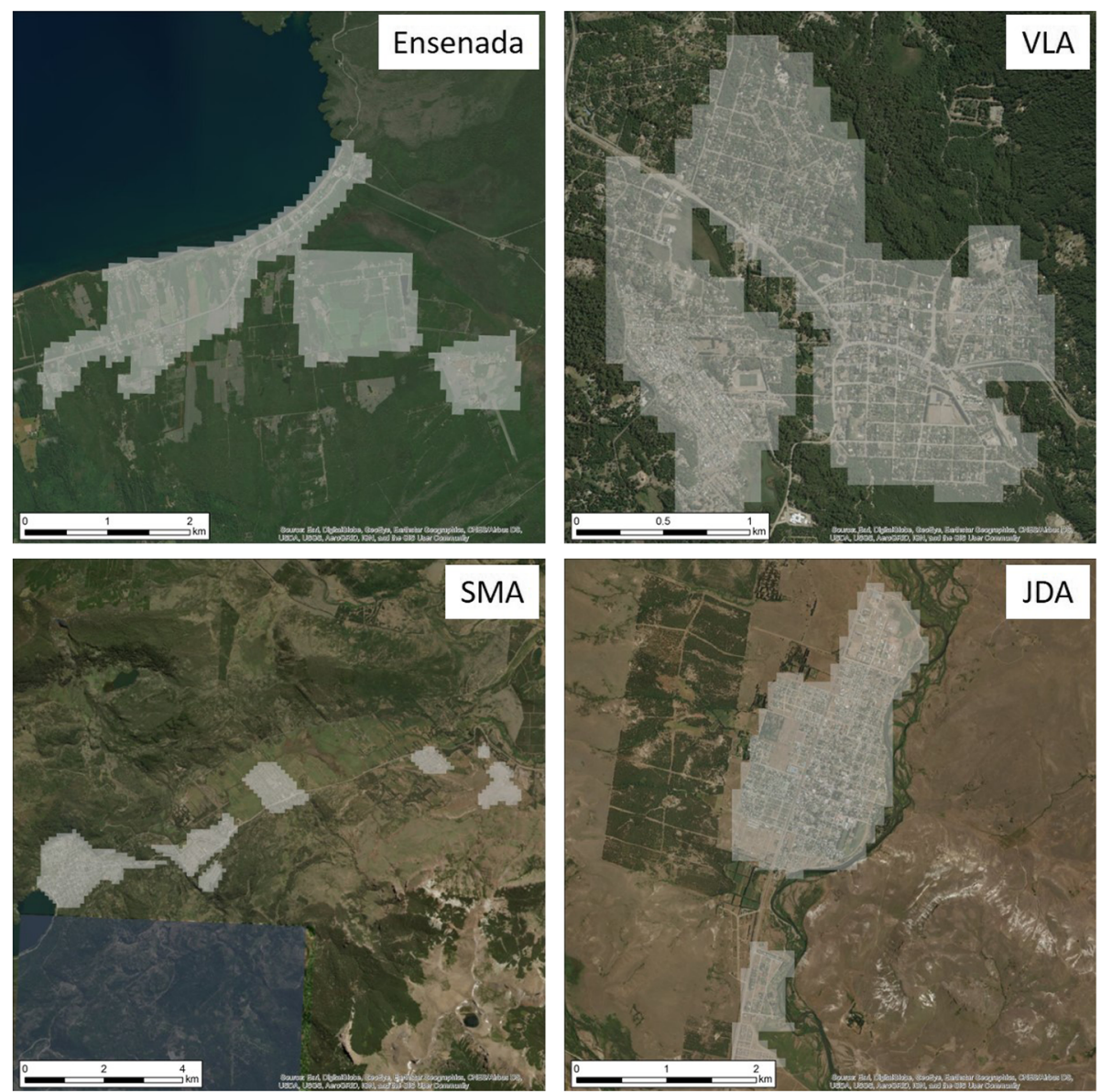

Fig. 9 Spatial extent (grey shaded area) of clean-up zones used for geospatial clean-up modelling. North at top. Aerial imagery sources: Esri, DigitalGlobe, GeoEye, i-cubed, USDA FSA, USGS, AEX, Getmapping, Aerogrid, IGN, IGP, swisstopo, and the GIS User Community 
Since OSM road lines are of a sufficient quality for our analysis, we converted OSM road lines into road area by creating a $3 \mathrm{~m}$ buffer (approximate width of a road lane in the area). We then determine the total area of the clean-up zone made up of the different urban surfaces using Eq. (1):

$$
\mathrm{T}=\mathrm{U} / \mathrm{S} \times \mathrm{A}
$$

where $\mathrm{T}=$ total impervious surface within the clean-up zone, $\mathrm{U}=$ the sum area of impervious surfaces within the sampled grid cells, $\mathrm{S}=$ the total area of sampled grid cells, and $\mathrm{A}=$ the total clean-up zone area.

We determine the quantity of tephra on each urban surface by multiplying urban surface area $\left(\mathrm{m}^{2}\right)$ by deposit thickness (m). Deposit thickness is based on published measurements and isopach maps, which we outline in detail in later sections.

Hayes et al. (2015) found that the proportional amount of tephra to be removed from urban areas scales with tephra accumulation. Thus, this scaling relationship needs to be considered when attempting to model the volume of tephra that must be removed from urban areas. Hayes et al. (2017) suggested that tephra thickness thresholds could be used to ensure tephra removal scaling is incorporated into the modelling process. The Hayes et al. (2017) thresholds that were developed for use within urban areas, and more specifically for metropolitan Auckland, New Zealand are used here (Table 2). Since Ensenada has a higher incidence of agricultural land use, we have also developed a refined model that incorporates the anecdotal information that only $\sim 30 \%$ of tephra on agricultural land was removed from farms exposed to over $100 \mathrm{~mm}$ of tephra. This means that for Ensenada tephra is removed from all impervious surfaces and roads, plus $30 \%$ of the tephra that was deposited on farmland.

\section{Uncertainty of tephra thickness and tephra removal volumes}

To evaluate how effective the modelling approach is at forecasting clean-up volume it is necessary that model outputs and reported volumes consider the same sources of uncertainty. For example, tephra can compact in a very short time and this will considerably influence the estimated volumes of tephra removed. In the subsections below we outline areas of uncertainty within our analysis and how we have quantified each so that reported and modelled estimates are considering the same sources of uncertainty.

Natural variability An assumption in the construction of tephra isopach maps is that thickness is uniform over local areas (Engwell et al. 2013). However, natural variability of the deposit can result in localised thickening or thinning (Engwell et al. 2013). Remobilisation of tephra deposits through aeolian, hydrological, or anthropogenic processes are also important sources of natural variability of tephra thickness locally (Blong et al. 2017; Collins and Dunne 1986; Collins et al. 1983; Wilson et al. 2011). Localised thickening can also occur in topographic low points (Engwell et al. 2013). Natural compaction of tephra can reduce tephra thickness by as much as $50 \%$ and much of it can occur in the first few weeks of deposition (Blong et al. 2017; Engwell et al. 2013; Hildreth and Drake 1992; Thorarinsson 1954). This means it is necessary to obtain tephra thickness measurements that are representative of the deposit variability. Therefore, the number of measurements made, time elapsed between deposition and measurement (potential for multiple fall events, remobilisation, and compaction), and locations of measurements are important sources of uncertainty. In this work we use the actual measurements made in or near each case study community. The exception to this is Ensenada, which exhibited a wide range in tephra thickness across the community $(0.1 \mathrm{~cm}$ to over $55 \mathrm{~cm})$ because it spanned the outer edge of the tephra deposit axis. Therefore, we use the isopach map published in Van Eaton et al. (2016) for Ensenada.

Observational error Studies assessing observational errors associated with making tephra thickness measurements have found ranges of 3-25\% (Le Pennec et al. 2012) and 2-65\% (Engwell et al. 2013). Bonadonna et al. (2015) also concluded that tephra thickness measurements

Table 2 Tephra clean-up thresholds used to assess tephra removal volumes for case study communities (adapted from Hayes et al. 2017)

\begin{tabular}{|c|c|c|c|}
\hline \multicolumn{2}{|c|}{ Hayes et al. (2017) thresholds } & \multicolumn{2}{|c|}{ Ensenada thresholds, refined for this study } \\
\hline Thickness (mm) & Surfaces for tephra removal & Thickness (mm) & Surfaces for tephra removal \\
\hline $1-10$ & Roads and airports & $1-10$ & Roads \\
\hline $10-200$ & $\begin{array}{l}\text { As above, with impervious surfaces } \\
\text { from private properties included }\end{array}$ & $10-100$ & $\begin{array}{l}\text { As above, with impervious surfaces } \\
\text { from private properties included }\end{array}$ \\
\hline$>200$ & Tephra removed from all surfaces & $\geq 100$ & $\begin{array}{l}\text { All impervious surfaces and } 30 \% \text { of } \\
\text { tephra from all other surfaces removed }\end{array}$ \\
\hline
\end{tabular}


associated with explosive volcanic eruptions can have a cumulative uncertainty of up to $\pm 30 \%$ when averaged across an entire deposit (5-20\% associated with observational uncertainty). We assign $\mathrm{a} \pm 30 \%$ error to each thickness measurement used in this study.

Determining tephra thickness in study locations We are reliant on published sources for data on the tephra thickness in each of our case study locations due to our volcanic impact reconnaissance trip taking place 19 months following the eruption of Calbuco. Published data on tephra thickness in each of our study locations demonstrates considerable uncertainty (Table 3). Thickness data sourced from Reckziegel et al. (2016) were reportedly collected shortly following the eruption and care was taken to ensure samples were pristine and unaffected by aeolian or hydrological remobilisation forces.

Geospatial data uncertainty Uncertainty associated with geospatial data could also influence modelling outputs as the extent of different urban surfaces is a key input into computing tephra removal volumes. Minor geospatial errors may have entered our analysis as our intention was not to digitise the urban fabric with a high level of precision, but to instead demonstrate that such data could be generated to a satisfactory standard quickly. As we were digitising from Digital Globe imagery, shadows can make urban features such as buildings appear larger than they are. Also, topological errors such as over- and undershoots, and slivers are possible (see: Maraş et al. 2010). Within the OSM data, it is possible some roads are missing or that some roads are wider or narrower than the 3 metre buffer we assigned. We include an assumed error of $\pm 5 \%$ to the digitised and OSM geospatial data to account for these potential sources of error.

Reported volume of tephra removed To compare our model outputs with observed events it is necessary to have accurately reported volumes of tephra that were removed from case study communities. However, it is rare that the volume of tephra that is removed from urban areas is precisely reported (Hayes et al. 2015). Estimates are often based on the number of truck loads or from tephra piles at disposal sites, which are not exact values (Hayes et al. 2015). It is difficult to ascertain whether volume estimates account for compaction that may have happened prior to tephra removal through natural or anthropogenic processes (e.g. dampening of deposit to reduce remobilisation) or subsequently after removal (process of loading onto truck, or at a disposal location). Given that tephra deposits can rapidly naturally compact by as much as 50\% (Blong et al. 2017) we assume an error of $\pm 50 \%$ to the estimates of tephra removal volumes.

\section{Clean-up operation duration}

Hayes et al. (2017) developed a geospatial network analysis approach to estimating clean-up duration to calculate how long it would take a fleet of trucks to transport a given distributed volume of tephra to predetermined tephra disposal sites. To estimate the duration of a clean-up operation, it is necessary to know how many truck loads are required to transport the tephra from pickup points to disposal sites. To evaluate tephra clean-up operation duration Hayes et al. (2017) developed Eq. (2; see Hayes et al. (2017) for details):

$$
T=\left(\left(F_{t} \times 2\right)+F_{c}\left(L_{t}+U_{t}\right)\right) / H_{d}
$$

where $\mathrm{T}=$ clean-up duration (days), $\mathrm{F}_{\mathrm{t}}=$ fleet hauling time, $F_{c}=$ number of truck loads to remove the tephra, $\mathrm{L}_{\mathrm{t}}=$ loading time, $\mathrm{U}_{\mathrm{t}}=$ unloading time, and $\mathrm{H}_{\mathrm{d}}=$ hours per day transportation works occur. Hayes et al. (2017) utilised high quality road network datasets for Auckland, New Zealand, to conduct geospatial network analysis between pickup points and disposal locations. In the present work, we do not have equivalent datasets. Instead, we utilised a conceptually similar, but modified Eq. (3):

Table 3 Tephra thickness measurements taken in or near the case study communities and used to model volume in this study

\begin{tabular}{|c|c|c|}
\hline Location & Minimum thickness $(\mathrm{cm})$ [source] & Maximum thickness $(\mathrm{cm})$ [source] \\
\hline Ensenada, Chile & 0.3 [Van Eaton et al. 2016] ${ }^{\mathrm{a}}$ & 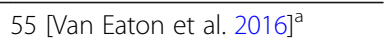 \\
\hline VLA & 0.2 [Reckziegel et al. 2016] $]^{\mathrm{b}}$ & 0.3 [Van Eaton et al. 2016] $]^{c}$ \\
\hline SMA & 0.5 [Reckziegel et al. 2016] $^{\mathrm{b}}$ & 3 [Van Eaton et al. 2016] ${ }^{d}$ \\
\hline JDA & 0.9 [Van Eaton et al. 2016] ${ }^{\mathrm{e}}$ & $>3$ [Van Eaton et al. 2016] ${ }^{\mathrm{f}}$ \\
\hline
\end{tabular}

a $27-30$ April 2015

b Date not published, but reportedly shortly following the eruption

c 3 July 2015

d 28 April 2015

e 4 July 2015

f 28 April 2015 


$$
T=\left(\left(T_{L} / N_{t}\right) \times\left(F_{t} \times 2\right)+\left(L_{t}+U_{t}\right)\right) / H_{d}
$$

where $\mathrm{T}=$ clean-up duration in days, $\mathrm{T}_{\mathrm{L}}=$ number of truck loads required (volumetric capacity of truck / total removal volume), $\mathrm{N}_{\mathrm{t}}=$ number of trucks available, $\mathrm{F}_{\mathrm{t}}=$ fleet hauling time (hours), $\mathrm{L}_{\mathrm{t}}=$ loading time (hours), $\mathrm{U}_{\mathrm{t}}=$ unloading time (hours), and $\mathrm{H}_{\mathrm{d}}=$ number of hours per day transportation works occur. The major simplification is that we have assumed an average travel time to disposal sites, rather than precise origindestination network modelling.

In Table 4 we outline the parameters used for tephra clean-up duration modelling. The six-wheeler trucks utilised to clean-up Ensenada have a maximum volumetric capacity of $\sim 10 \mathrm{~m}^{3}$, whereas the smaller four-wheeler trucks utilised in the other case study locations have a maximum capacity of $\sim 5 \mathrm{~m}^{3}$ (Hayes et al. 2017). Not all trucks will be filled to capacity: it is probable that some will be underfilled. To account for this we have assumed that a truck will be at least $75 \%$ of its maximum capacity before travelling to a disposal site. To determine the number of truck loads $\left(\mathrm{T}_{\mathrm{L}}\right)$ for Ensenada and JDA we use the total volume reported by interview participants as being volume removed $( \pm 50 \%)$ divided by the volumetric capacity of the trucks. For SMA, an interview participant estimated that 2500 truckloads were taken to the disposal site, so we use this value rather than deriving $\mathrm{T}_{\mathrm{L}}$. We have no estimates of volume removed at VLA, so we have utilised estimates based on our geospatial modelling approach outlined above. We also use modelled volumes for the other three case study communities to compare how the results differ depending on whether using modelled volumes or reported volumes.

The number of trucks $\left(\mathrm{N}_{\mathrm{T}}\right)$ utilised for each of our case study locations are based on interview participants' estimates as well as estimates made by officials in local media. For VLA, SMA, and JDA estimates are based on the number of 'road teams', which consisted of both diggers and trucks. We have assumed a 1:1 ratio of diggers to trucks. We note that the number of trucks utilised in a clean-up operation can fluctuate from a small initial number to a peak corresponding to when reinforcements arrive, before a decline as demand decreases. We assume that truck numbers reported to us reflect peak deployment. However, for JDA it was reported that initially only ten trucks were used until further reinforcements arrived. We do not know the exact amount of time ten trucks were used or when other assets arrived, so we have accounted for this uncertainty by including a range of 10-25 trucks used for JDA clean-up.

The time it takes for a truck to travel to or from a disposal site $\left(\mathrm{F}_{\mathrm{t}}\right)$ is estimated based on using drive time estimates from the centre of each case study town to a disposal site. We have set the loading and unloading times as static at $5 \mathrm{~min}$ for each. Finally, each of our case study locations continued clean-up activities for approximate $8 \mathrm{~h}$ per day.

\section{Monte Carlo modelling}

As with Hayes et al. (2017), we utilise Monte Carlo sampling (10,000 iterations) as a method to incorporate uncertainty into the modelling approach. This involves assigning probability distributions around uncertain parameters within the equations described in the above subsections (e.g. duration to disposal site, total area affected, tephra thickness). We have used uniform distributions to represent each of the uncertain parameters. We provide the spreadsheets used to compute these values in Additional file 1. We present our modelling outputs as probability of exceedance as this illustrates the uncertainty associated with the modelling outputs. This also allows for superimposing of the reported volume of tephra that was removed to illustrate how the modelling outputs compare with the reported volumes.

\section{Results}

Surface area of clean-up zones

We present the results of our geospatial analysis of urban surfaces in each case study location in Table 5 . Ensenada has the lowest proportion of urban surfaces requiring clean-up (0.4-2\%) out of our case study communities, with VLA (10\%), JDA (13\%), and SMA (18\%) containing considerably higher proportions of impervious surfaces. No settlements in Ensenada were exposed to tephra fall of less the $100 \mathrm{~mm}$ (only roads), which is why no impervious surfaces (building footprint or paved areas) were sampled.

\section{Volume removed}

We present the modelling outputs as a probability of exceedance compared to the reported volume of tephra

Table 4 Parameters used to model tephra clean-up operation duration

\begin{tabular}{llllllll}
\hline Parameter & Truck capacity $\left(\mathrm{m}^{3}\right)$ & $\mathrm{T}_{\mathrm{L}}$ & $\mathrm{N}_{\mathrm{t}}$ & $\mathrm{F}_{\mathrm{t}}$ (hours) & $\mathrm{L}_{\mathrm{t}}$ (hrs) & $U_{t}$ (hrs) & $H_{d}$ (hrs) \\
\hline Ensenada & $7.5-10$ & $15,000-60,000$ & 60 & $0.375-0.5$ & 0.08 & 0.08 & 8 \\
VLA & $3.75-5$ & $822-2657$ & 3 & $0.2-0.25$ & 0.08 & 0.08 & 8 \\
SMA & N/A & 2500 & 7 & $0.2-0.25$ & 0.08 & 0.08 & 8 \\
JDA & $3.75-5$ & $4000-16,000$ & $10-25$ & 0.2 & 0.08 & 0.08 & 8 \\
\hline
\end{tabular}


Table 5 Geospatial analysis of urban surfaces in case study locations. N/a indicates that no grid cells fell within these thickness ranges

\begin{tabular}{|c|c|c|c|c|c|c|}
\hline Location & $\begin{array}{l}\text { Area of } \\
\text { exposed assets } \\
\left(\mathrm{m}^{2}\right)\end{array}$ & $\begin{array}{l}\text { Area } \\
\text { sampled } \\
\left(\mathrm{m}^{2}\right)\end{array}$ & $\begin{array}{l}\text { Sampled area that is } \\
\text { impervious surface }\left(\mathrm{m}^{2}\right)\end{array}$ & $\begin{array}{l}\text { Percentage of total area } \\
\text { that is impervious surface (\%) }\end{array}$ & $\begin{array}{l}\text { Extrapolated area that is } \\
\text { impervious surface }\left(\mathrm{m}^{2}\right)\end{array}$ & $\begin{array}{l}\text { Total area of } \\
\text { road }\left(\mathrm{m}^{2}\right)\end{array}$ \\
\hline $\begin{array}{l}\text { Ensenada } 1-5 \\
\text { mm }\end{array}$ & 20,000 & 0 & $\mathrm{n} / \mathrm{a}$ & $\mathrm{n} / \mathrm{a}$ & $\mathrm{n} / \mathrm{a}$ & 20,000 \\
\hline $\begin{array}{l}\text { Ensenada }>5- \\
10 \mathrm{~mm}\end{array}$ & 27,000 & 0 & $\mathrm{n} / \mathrm{a}$ & $\mathrm{n} / \mathrm{a}$ & $\mathrm{n} / \mathrm{a}$ & 27,000 \\
\hline $\begin{array}{l}\text { Ensenada }> \\
10-20 \mathrm{~mm}\end{array}$ & 14,000 & 0 & $\mathrm{n} / \mathrm{a}$ & $\mathrm{n} / \mathrm{a}$ & $\mathrm{n} / \mathrm{a}$ & 14,000 \\
\hline $\begin{array}{l}\text { Ensenada > } \\
20-30 \mathrm{~mm}\end{array}$ & 14,000 & 0 & $\mathrm{n} / \mathrm{a}$ & $\mathrm{n} / \mathrm{a}$ & $\mathrm{n} / \mathrm{a}$ & 14,000 \\
\hline $\begin{array}{l}\text { Ensenada > } \\
30-60 \mathrm{~mm}\end{array}$ & 60,000 & 0 & $\mathrm{n} / \mathrm{a}$ & $\mathrm{n} / \mathrm{a}$ & $\mathrm{n} / \mathrm{a}$ & 60,000 \\
\hline $\begin{array}{l}\text { Ensenada }> \\
60-100 \mathrm{~mm}\end{array}$ & 99,000 & 0 & $\mathrm{n} / \mathrm{a}$ & $\mathrm{n} / \mathrm{a}$ & $\mathrm{n} / \mathrm{a}$ & 99,000 \\
\hline $\begin{array}{l}\text { Ensenada > } \\
100-150 \mathrm{~mm}\end{array}$ & 146,000 & 51,000 & 1000 & 2 & 3000 & 70,000 \\
\hline $\begin{array}{l}\text { Ensenada }> \\
150-200 \mathrm{~mm}\end{array}$ & $5,163,000$ & $1,305,000$ & 26,000 & 2 & 102,000 & 146,000 \\
\hline $\begin{array}{l}\text { Ensenada > } \\
\text { 200-300 mm }\end{array}$ & 878,000 & 236,000 & 1000 & 0.4 & 3000 & 28,000 \\
\hline $\begin{array}{l}\text { Ensenada > } \\
300 \mathrm{~mm}\end{array}$ & 15,000 & 0 & $\mathrm{n} / \mathrm{a}$ & $\mathrm{n} / \mathrm{a}$ & $\mathrm{n} / \mathrm{a}$ & 15,000 \\
\hline VLA & $4,220,000$ & $2,010,000$ & 196,000 & 10 & 412,000 & $1,175,000$ \\
\hline SMA & $7,530,000$ & $2,550,000$ & 451,000 & 18 & $1,330,000$ & $1,467,000$ \\
\hline$J D A$ & $4,910,000$ & $2,150,000$ & 288,000 & 13 & 658,000 & 942,000 \\
\hline
\end{tabular}

removed in Fig. 10. For Ensenada, only the 'refined' model fits within the range of the reported removal volume, and the expected tephra removal volume is 450, $000 \mathrm{~m}^{3}$. For SMA, the expected value for the tephra removal volume is $33,000 \mathrm{~m}^{3}$, which falls outside the upper limit of the reported volume of tephra removed. The 'road only' and 'road and impervious surface' models result in a $>70 \%$ probability of the volume that falls outside of the upper limit of the reported volume range. The 'total removal' model results in 100\% probability of exceeding the reported volume range. The 'roads and impervious surface' model for JDA appears to almost perfectly match the tephra removal uncertainty range, and the expected value of $38,000 \mathrm{~m}^{3}$ is similar to the reported volume of about $40,000 \mathrm{~m}^{3}$. We do not have any data on the reported volume removed from VLA, but our estimates appear reasonable considering the thinner tephra fall and less exposed surfaces in SMA and JDA.

\section{Clean-up duration}

We present the total clean-up operation duration modelling outputs as probability of exceedance and compare to reported clean-up duration in Fig. 11. Estimates of clean-up operation duration for roads appear to broadly reflect the reported duration (Fig. 11). However, for Ensenada the duration for total clean-up including private properties appears to be considerably underestimated. Using modelled tephra volume, VLA clean-up appears to underestimate the clean-up duration, but only by a few days. Large uncertainties of the tephra removal volume contribute to considerable ranges for clean-up operation duration for both SMA and JDA. Using the reported removal volume for SMA, the expected value for the clean-up duration is 4 weeks, which is half the reported duration. Using the modelled tephra removal produces an expected value for clean-up operation duration of 13 weeks, approximately 5 weeks longer than the reported duration. For JDA, curves using the modelled and reported volumes produce similar outputs. The reported duration of clean-up in JDA was 6 weeks, which is the same as the expected value for clean-up duration for both the modelled and reported tephra volume.

\section{Discussion}

Performance of the geospatial clean-up model

Hayes et al. (2015) found that clean-up operations are influenced by complex interactions between physical factors (e.g. erupted volume, column height, grainsize, wind speed and direction, and rainfall) and social factors (e.g. 

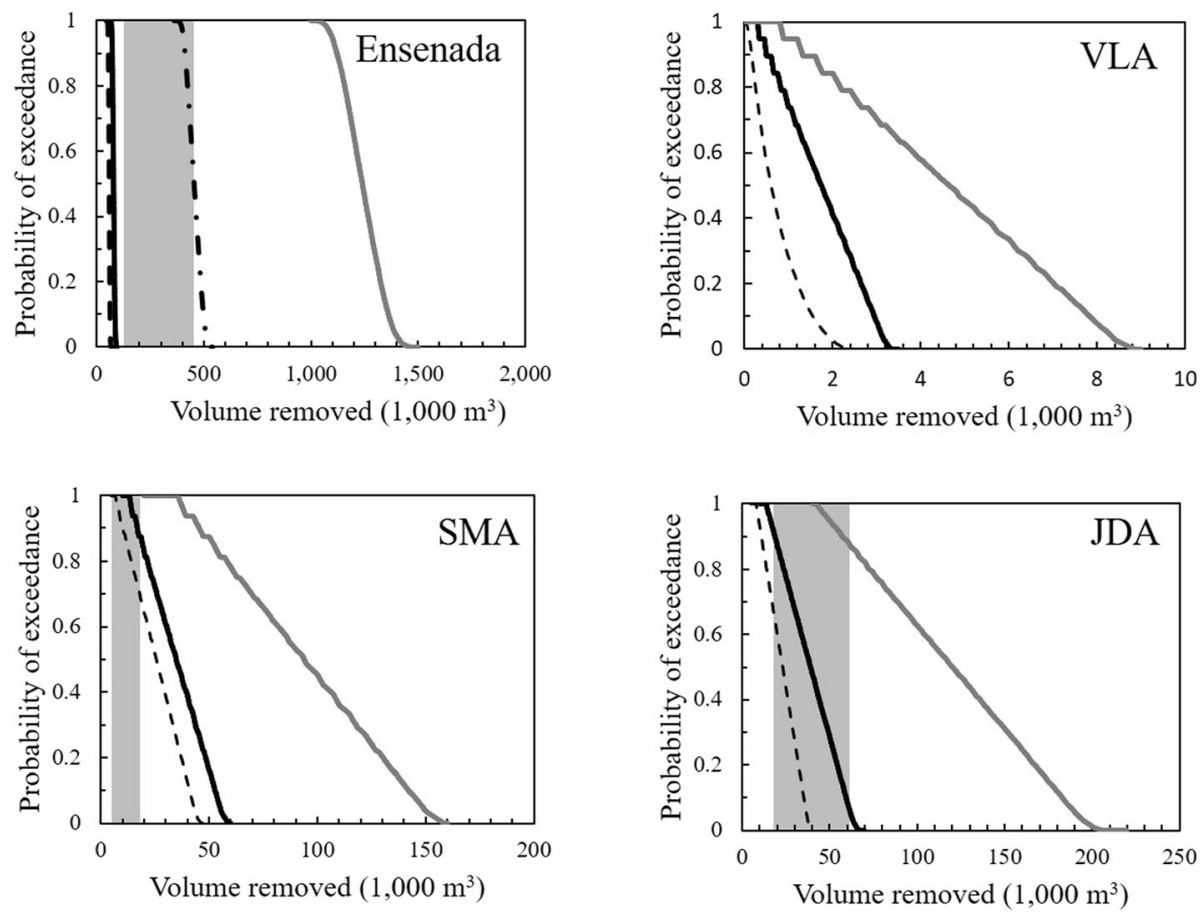

- . . Ensenada refined

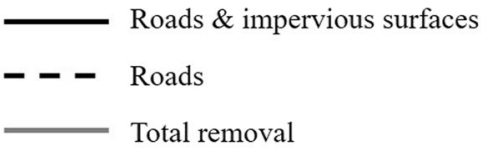

Fig. 10 Geospatial model volumes. Grey shaded area = range of reported volume removed. Note: No reported removal data for VLA

social priorities, prior planning, previous experience, and infrastructure interdependencies). Insufficient evidence is currently available to quantitatively account for each of these factors, which means logical simplifications have been required to quantitatively geospatially model tephra clean-up. In the following subsections, we discuss how the conceptual geospatial model put forward by Hayes et al. (2017) performed when evaluated against real observations from clean-up in four communities in Chile and Argentina following the 2015 Calbuco eruption. We evaluate the model outputs both in their accuracy and precision to reproduce the reported values of removal volumes and clean-up operation durations, as well as the relative utility of the modelling results.

\section{Forecasting removal volume}

Many factors might be influencing model outputs and need to be considered when forecasting the volume of tephra that requires removal after a tephra fall. These factors include: erosion and compaction of tephra deposits (Blong et al. 2017), affected land use (Hayes et al. 2015), road types (Blake et al. 2017), infiltration into storm water systems (Wardman et al. 2012), quantity of tephra disposed onsite or left in situ and not included in reported volume estimates (e.g. in a garden) (Magill et al. 2013), and uncertainty and error associated with tephra measurements (Engwell et al. 2013; Bonadonna et al. 2015). Below, we discuss each of these factors in the context of the case studies investigated in this work and considerations that future workers should consider if applying the Hayes et al. (2017) conceptual model.

Erodibility of the deposit is an important factor when considering whether tephra is removed from roads across the four case-study communities, in particular the potential for the tephra to become airborne. In Ensenada, tephra deposits were sufficiently coarse (see Table 1) and dense to not warrant stabilisation at disposal sites, nor were stabilisation and clean-up efforts undertaken on local gravel roads. In comparison the deposited tephra in JDA was very fine-grained (see Table 1) and easily remobilised, which prompted greater clean-up of tephra on gravel/dirt roads in the township. Thus, it appears that when clean-up volumes are to be modelled it is necessary to consider the road surface type that tephra is being deposited on and whether the tephra is likely to become airborne (e.g. tephra characteristics and climate) and cause further impacts for the affected community. 

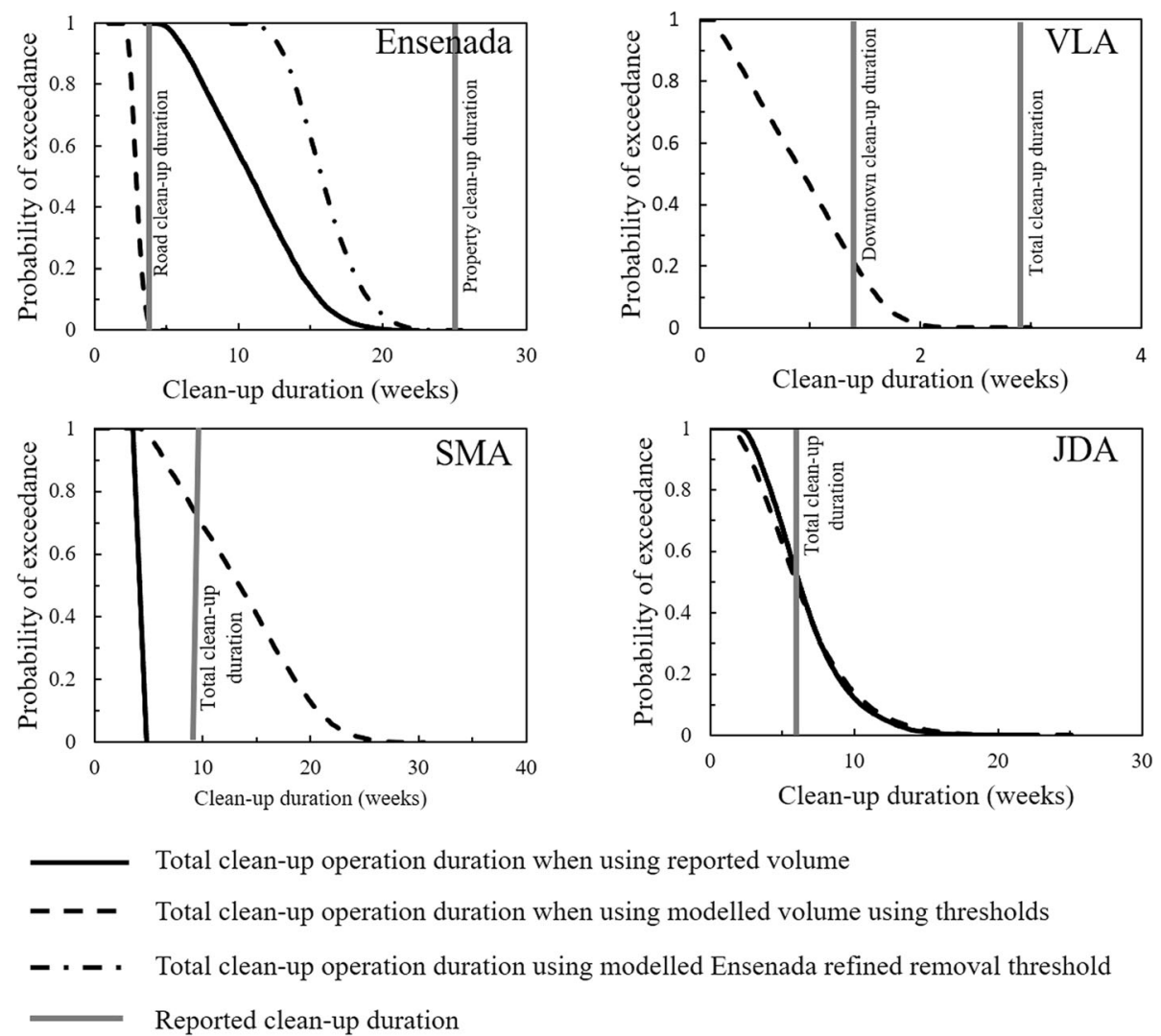

Fig. 11 Clean-up duration modelling outputs. Note: no reported volume for VLA

Hayes et al. (2015) suggested that land use is an important component of clean-up requirements. Ensenada is considerably different to other case study communities since much of the affected area was farm land. Since we do not know the farms that removed tephra and those that did not, we assumed that all farms affected removed at least one third of the volume of tephra that fell on their property (refined model). However, some farms did not remove any tephra, which may contribute to the over-estimation. Thus, although similar land use can be affected by the same degree of tephra deposition the response at the individual property level may differ, which can influence model outputs. This is particularly pronounced in the Ensenada case study due to the relatively large land parcel sizes and sparsely distributed population.

Road types can strongly influence the volume of tephra removed following a tephra fall (Hayes et al. 2017). For example, there are many gravel or dirt roads in SMA and JDA from which officials said deposited tephra need not be completely removed. Unfortunately, OSM road data does not include road surface type. We are unsure of the proportion of deposited tephra that fell on dirt roads that was removed, and so do not provide a more refined modelled estimate of tephra removal factoring this in. Model tephra clean-up volume estimates were also very high for Ensenada, which similarly has a number of local dirt roads. Our observations during our field visit suggest tephra was only graded to the side of the dirt roads. The model performed comparatively well in JDA despite having only one paved road (Route 40). Thus, the presence of dirt roads may not be the sole factor influencing overestimation of tephra removal volumes.

Infiltration of tephra into storm water systems can cause localised flooding following a tephra fall (Blong 1984; Wardman et al. 2012; Wilson et al. 2011). An unspecified amount of tephra entered into the storm water system in SMA and was transported directly into Lake Lácar, eventually provoking blockages. Although a small amount of tephra was removed from the storm water system to clear blockages, it is unclear whether tephra removed from the storm water system contributed to the reported estimated removal volume. However, even if this tephra was included in the reported removal volume, it is unlikely this is the sole source of error as the pipes in SMA are small and unlikely to have capacity to hold the sufficient volume of tephra to account for the discrepancy. Thus, tephra entering the SMA storm water system could be a supplementary, but 
unquantified, reason for the overestimation of model outputs.

A common strategy of tephra clean-up operations is to remove the bulk tephra and then wash the surfaces. This occurred in each of our case study locations, but information is unavailable to quantify the proportion of tephra that was washed rather than removed. This may partially explain over-estimation of volume removal as some material was not removed, but rather washed to the roadside where it is left to erode. Even after surface washing it is common for a fine coating or residue of tephra to remain in urban areas after official clean-up operations have ceased (e.g. Blake et al. 2015). Another potential source for model over-estimation is that individual property owners may clean-up to different standards and/or they may store ash on their own property rather than relying on municipal clean-up. Hayes et al. (2017) indicated that this was a limitation of the approach they undertook for Auckland, New Zealand, and would likely mean modelling outputs are overestimated. We suggest that although these results are promising, more detailed examinations of clean-up efforts from future tephra falls should gather information on the tephra that remains in place after clean-up operations. In particular, direct observation and tracking through a waste management information system would be highly useful (e.g. Brown et al. 2011).

Large uncertainties are common place in disaster risk assessment, but this information is still a critical part of response and recovery planning as it provides information that can help inform policy and procedures (Zerger 2002; Murnane et al. 2016; Crawford et al. 2018). For disaster waste assessments, order-of-magnitude estimates are often considered sufficient for planning purposes (e.g. identifying resource requirements) (FEMA 2007; Tonkin and Taylor 2018). Uncertainty ranges in our analysis are large primarily because of considerable uncertainties associated with tephra thickness measurements. Uncertainty would be less when modelling for pre-eruption impact assessments as it is typical that the model outputs from tephra deposition models provide either uncompacted thickness or loading $\left(\mathrm{g} / \mathrm{cm}^{2}\right)$, so the modeller can take corrective action to factor in potential deposit compaction. Precise estimates of tephra volume (e.g. $20,000 \mathrm{~m}^{3}$ compared to $23,000 \mathrm{~m}^{3}$ ) are probably unnecessary: order of magnitude estimates are more appropriate (e.g. 20,000-40,000 $\mathrm{m}^{3}$ ). Although our model outputs appear to overestimate tephra removal for Ensenada and SMA, the estimates are considerably closer to the reported removal volumes than if we assumed that the entire tephra deposit was removed. The model successfully reproduced the removal volumes reported in JDA when using the thresholds from
Hayes et al. (2017). Unfortunately, we do not have a reported removal volume for VLA, but the model outputs appear reasonable when compared to JDA and SMA (less tephra deposition in VLA) and given that clean-up was handled using existing staffing capacity. We consider the quantitative modelling approach undertaken here for estimating tephra removal volumes to be an effective and useful method for pre-event impact and risk assessments and could also be usefully deployed immediately post-eruption as a component of a rapid impact assessment, so long as uncertainties such as those outlined here and Hayes et al. (2017) are appropriately considered.

\section{Forecasting clean-up operation duration}

Hayes et al. (2017) suggested that due to a range of factors (e.g. remobilisation, operational inefficiencies, evacuation/exclusion requirements, lack of prior experience), their conceptual approach to clean-up operation duration modelling will likely under-estimate the duration of clean-up. Our findings here do not systematically under-estimate clean-up operation duration, suggesting that the interaction between the above components is not simple. Below we discuss additional insights into clean-up operation duration modelling derived from this work.

The clean-up duration model assumes a constant cleanup rate throughout the clean-up effort (Hayes et al. 2017). However, clean-up operations are dynamic. They often start slowly as impact assessments are undertaken and authorities get a sense of the scale of the problem and resource requirements, and then additional resources arrive, reaching a peak in activity, and then decay for the final phases before back to business-as-usual levels. This appears to have been the case in JDA, where clean-up operations initially utilised two dump trucks in each of the five clean-up sectors (10 dump trucks in total), but this increased to 50 dump trucks for an unknown duration after the first week. Additionally, analysis of the rate of cleanup using cumulative volumes reported in the media suggest that the average rate throughout the entire cleanup $\left(\sim 1900 \mathrm{~m}^{3}\right.$ per day) is over double the rate removed in the first 6 days of the clean-up operation $\left(\sim 800 \mathrm{~m}^{3}\right.$ per day). This demonstrates the importance of understanding the temporal dynamics of tephra clean-up operations for more robust model outputs. We suggest spatio-temporal dynamics as an important area of future research not only for tephra clean-up but for general disaster response and recovery efforts.

Our modelled clean-up operation duration estimates for Ensenada appear optimistic (Fig. 11). A complicating factor for this is that much of the Ensenada economy is based on tourism, and many of the properties are 
vacation homes. Thus, removal of tephra from some properties took considerably longer because the owners did not return to clean-up their properties for months. During our visit to the area 19 months after the eruption, many properties still had tephra. Therefore, we suggest this model for estimating tephra clean-up durations is ill-suited to sparsely populated towns with relatively low levels of permanent occupation.

Hayes et al. (2015) suggested that prior experience with tephra clean-up could be a valuable factor for increasing the efficiency of future clean-up operations, due to having an experienced population and municipal authorities with a clean-up plan that can be utilised in the future. This appears to be partially true for VLA, which had experience cleaning up tephra from the 2011 Cordón Caulle volcanic complex eruption. Inhabitants knew the basics of clean-up and what to expect and potential disposal sites were already identified. However, as the Calbuco tephra deposition event was considerably smaller in both volume and duration compared to the Cordón Caulle eruption, we cannot draw robust conclusions about whether the response was truly stress-tested. We note that prior experience can also cause problems during clean-up as authorities and/or the population expect that clean-up will occur in the same manner as previous operations. SMA found the Calbuco tephra clean-up to be considerably more difficult than the Cordón Caulle tephra fall clean-up. The interview participants stated the 2011 Cordón Caulle tephra fall clean-up experience led them to believe that the storm water system could cope well with tephra ingestion and that this could be used for future tephra clean-up operations. However, during the 2015 Calbuco clean-up, the tephra caused blockages, which they attributed to the finer grainsize, and tephra had to be removed using vacuum trucks. So, while previous experience can be useful, each tephra clean-up needs to consider the wide spectrum of potential characteristics of deposited tephra.

Finally, the model here assumes a single coordinated clean-up operation. Remobilisation of tephra from 'ash storms' may require multiple clean-up efforts to be undertaken over many years (Wilson et al. 2011). The model presented here has not evaluated secondary clean-up efforts that could be required, particularly in JDA where the climate is relatively dry and potential for remobilisation relatively high.

\section{Developing disaster waste management models for pre- event planning}

Planning for future impactful events is a core function of contemporary emergency management. Hayes et al. (2017) demonstrated how a conceptual model of volcanic disaster waste could be constructed to assess the likely waste burden from a future volcanic eruption. In this paper, we have used data collected after the Calbuco 2015 eruption to test whether the Hayes et al. (2017) model produces outputs that are sufficiently accurate for emergency planning purposes. Using standard tephra hazard modelling techniques, it is possible to use the conceptual approach of Hayes et al. (2017) and the modified approach in this paper to model tephra cleanup requirements for potential future eruptions at other volcanoes. However, it is necessary to consider the uncertainty and influence on modelling outputs of local contextual factors such as: data quality of asset databases, community tolerance towards ashy environments, land use, climate, socio-economic factors (e.g. reliance on tourism trade), and access to resources. These factors were alluded to in Hayes et al. (2017) and supported by the findings in this paper.

Substantial volumes of tephra can be deposited on the slopes of volcanoes during and following volcanic eruptions that can later be remobilised through aeolian (e.g. Wilson et al. 2011; Arnalds et al. 2013; Liu et al. 2014; Forte et al. 2018) or fluvial (e.g. Lecointre et al. 2004; Lavigne and Thouret 2003; van Westen and Daag 2005) processes and require clean-up. The modelling in this paper has not incorporated remobilisation of tephra as a potential input. Integrating tools that evaluate potential remobilisation of tephra deposits (e.g. Major et al. 2000; Gran et al. 2011; Reckziegel et al. 2016) into disaster waste assessment may be necessary for recovery planning in situations where remobilisation is likely.

Additional waste streams can be generated from volcanic eruptions, which we did not consider in our modelling. For example, damage from volcanic hazards can require removal of debris generated from damaged or collapsed buildings and/or damaged or soiled contents. This was the case in Ensenada, where the 2015 Calbuco eruption destroyed and damaged buildings (Hayes et al. 2019a). Disaster waste assessment frameworks have been developed for other natural hazards (e.g. earthquakes, tsunami, flood, hurricanes) that links damage (e.g. using fragility functions and/or damage state frameworks) to an estimate of the likely quantity of waste that is generated (e.g. FEMA 2013a, b, c; Brown 2014; García-Torres et al. 2017). Most of these approaches assume that the quantity of waste generated is proportional to the percentage damage to a structure (e.g. $80 \%$ damage equals $80 \%$ of the total structure becoming debris), but few of these studies have been evaluated using real post-disaster waste data. A similar framework for the spectrum of volcanic hazards would be of value to more comprehensively assess disaster waste after volcanic eruptions. We do not have any data that indicates the quantity of waste that was generated from the Calbuco eruption to use 
in this study. Collection of this information as part of post-eruption impact assessments would be of value to developing and refining disaster waste assessment frameworks for volcanic eruptions.

\section{Conclusions}

Tephra clean-up is a fundamental component of posteruption response and recovery. Planning for clean-up after volcanic eruptions is necessary for best practice volcanic risk mitigation. Utilising impact and risk assessments is one way to gain useful insights into the cleanup requirements under different eruption scenarios. In this study we have gathered useful insights into the opportunities and challenges associated with using geospatial modelling as a tool for clean-up operation planning by studying the clean-up experiences after the 2015 Calbuco eruption of four communities in Chile and Argentina. Each community experienced differing challenges associated with their clean-up operations and each had differing priorities. We have evaluated the performance of quantitative geospatial tephra clean-up modelling as a method for gaining insights into tephra clean-up requirements. Our results demonstrate that the relatively simplistic geospatial analysis yields credible and usable estimates of tephra volume to be removed and tephra clean-up operation durations. Our results support the assertion in Hayes et al. (2017) that the model would likely over-estimate removal volumes. This is because the model assumes $100 \%$ of tephra on any given surface is removed and asset sub-classes (e.g. different road typologies) and potential stormwater system infiltration are not considered. Hayes et al. (2017) also indicated that the model would possibly underestimate the clean-up duration, but we did not find this to be systemically the case. This points toward the dynamic nature of clean-up operations, which require further analysis in future work. It is necessary to consider potential sources of uncertainty across the hazard, exposure, and vulnerability domains. As a priority, we consider it important to iteratively collect information relating to the experiences of communities conducting tephra clean-up operations to fill the gap in empirical information regarding tephra clean-up operations. We have demonstrated potential areas of confusion if data are not collected carefully. As a next step towards greater understanding of tephra clean-up, we suggest that gathering data and analysing the spatial and temporal dynamics of tephra clean-up operations will yield useful information on priorities and demand for resources through a clean-up response. Additionally, other forms of waste (e.g. construction and demolition, electronics, perishable) can be generated from a variety of volcanic hazards, yet there is very little information detailing how other types of waste are managed. We suggest more comprehensive analysis of waste management following volcanic eruptions is necessary.

Although we have applied this analysis to select locations in Chile and Argentina, there are many communities around the world that are exposed to future tephra hazards and are similar to the communities studied in this paper. Our results demonstrate that our simplified clean-up model provides useful information even with differing contextual factors (urban fabric, climate, and resource availability), the large uncertainties around tephra measurements, estimates of removal volumes and the dynamic aspects of clean-up operations. This suggests that this approach for identifying potential clean-up operation requirements is useful as part of pre-event response and recovery planning.

\section{Additional file}

Additional file 1: Calbuco tephra clean-up model using Monte Carlo simulation. (XLSX $2170 \mathrm{~kb}$ )

\section{Abbreviations}

JDA: Junín de los Andes; MINAGRI: Chilean Ministerio de Agricultura; MOP: Ministerio de Obras Públicas (Ministry of Public Works); ONEMI: Oficina Nacional de Emergencia del Ministerio del Interior (National Emergency Office of the Ministry of the Interior); OSM: Open Street Map; SMA: San Martín de los Andes; VEl: Volcanic Explosivity Index; VLA: Villa La Angostura

\section{Acknowledgements}

The University of Canterbury Human Ethics Committee reviewed and approved the methodological approach used for this research (HEC 2016/69/LR-PS). We are indebted to interview participants in Chile and Argentina who kindly offered up their time to talk to us about their tephra clean-up experiences. We also thank Rodrigo Calderon and Lizette Bertin of SERNAGEOMIN for logistical and translation support in Chile. We acknowledge Daniel Blake, George Williams and Tyler Barton for assistance with data collection in Argentina. We are grateful to two anonymous reviewers and editor David Damby for constructive and useful comments that improved the quality of this manuscript.

\section{Authors' contributions}

JLH drafted the manuscript with input from TMW, CS, GV, PS, DB, VO, NID, GSL. All authors contributed to field interviews and data collection. All authors read and approved the final manuscript.

\section{Funding}

We gratefully acknowledge funding support from the Ministry of Business, Innovation and Employment Natural Hazard Research Platform Research (Contact C05X0907 and Project 2015-MAU-01-NHRP), Resilience to Natures Challenges (GNS-RNC003), the New Zealand Earthquake Commission and Auckland Council through the DEVORA project, GNS Science SIIF Research Funding, and Mason Trust.

\section{Availability of data and materials}

The Monte Carlo simulation is available in the Additional file 1. There are no other associated data with this paper.

\section{Competing interests}

The authors declare that they have no competing interests.

\section{Author details}

${ }^{1}$ Department of Geological Sciences, University of Canterbury, Private Bag 4800, Christchurch 8140, New Zealand. 'ªssey University Wellington, Wallace Street, Mt Cook, Wellington 6021, New Zealand. ${ }^{3}$ IPATEC (Instituto Andino-Patagónico de Tecnologías Biológicas y Geoambientales), CONICET/ UNCO, Av. de los Pioneros 2350, 8400 S. C. de Bariloche, Argentina. ${ }^{4}$ Centro Regional Universitario Bariloche, Universidad Nacional del Comahue, Quintral 
1250, 8400 S.C. de Bariloche, Argentina. ${ }^{5}$ GNS Science, PO Box 30368, Lower Hutt 5040, New Zealand.

\section{Received: 30 January 2019 Accepted: 12 August 2019}

Published online: 23 August 2019

\section{References}

Alloway BV, Pearce NJG, Villarosa G, Outes V, Moreno PI. Multiple melt bodies fed the AD 2011 eruption of Puyehue-Cordón Caulle, Chile. Sci Rep. 2015; 5(17589):1-8. https://doi.org/10.1038/srep17589.

Arnalds O, Thorarinsdottir EF, Thorsson J, Waldhauserova PD, Agustsdottir AM. An extreme wind erosion event of the fresh Eyjafjallajökull 2010 volcanic ash. Sci Rep. 2013;3:1257. https://doi.org/10.1038/srep01257.

Aspinall WP, Blong R. Volcanic risk assessment. In: Sigurdsson H, editor. Encyclopedia of volcanoes. 2nd ed. San Diego: Academic; 2015. p. 1215-31. https://doi.org/10.1016/B978-0-12-385938-9.00070-5.

Bakkensen LA, Fox-Lent C, Read LK, Linkov I. Validating resilience and vulnerability indices in the context of natural disasters. Risk Anal. 2016;37(5): 982-1004. https://doi.org/10.1111/risa.12677.

Baxter PJ, Aspinall WP, Neri A, Zuccaro G, Spence RJS, Cioni R, Woo G. Emergency planning and mitigation at Vesuvius: a new evidence-based approach. J Volcanol Geotherm Res. 2008;178(3):453-73. https://doi.org/10.1016/j. jvolgeores.2008.08.015.

Beguería S. Validation and evaluation of predictive models in hazard assessment and risk management. Nat Hazards. 2006;37(3):315-29. https://doi.org/10.1 007/s11069-005-5182-6.

Biass S, Frischknecht C, Bonadonna C. A fast GIS-based risk assessment for tephra fallout: the example of Cotopaxi volcano, Ecuador: part II: vulnerability and risk assessment. Nat Hazards. 2012;64(1):615-39. https:/doi.org/10.1007/s11069-012-0270-X.

Biass S, Todde A, Cioni R, Pistolesi M, Geshi N, Bonadonna C. Potential impacts of tephra fallout from a large-scale explosive eruption at Sakurajima volcano, Japan. Bull Volcanol. 2017;70:73. https://doi.org/10.1007/s00445-017-1153-5.

Blake DM, Wilson G, Stewart C, Craig H, Hayes JL, Jenkins SF, Wilson TM, Horwell CJ, Daniswara R, Ferdiwijaya D, Leonard GS, Hendrasto M, Cronin S (2015) Impacts of the 2014 eruption of Kelud volcano, Indonesia on infrastructure, utilities, agriculture, and health. GNS Science Report 2015/15.

Blake DM, Wilson TM, Cole JW, Deligne NI, Lindsay JM. Impact of volcanic ash on road and airfield surface skid resistance. Sustainability. 2017;9(8):1389. https:// doi.org/10.3390/su9081389.

Blong R, Enright N, Grasso P. Preservation of thin tephra. J Appl Volcanol. 2017;6: 10. https://doi.org/10.1186/s13617-017-0059-4.

Blong RJ. Volcanic hazards: a sourcebook on the effects of eruptions. Sydney and Orlando: Academic; 1984

Bonadonna C, Biass S, Cost A. Physical characterization of explosive volcanic eruptions based on tephra deposits: propagation of uncertainties and sensitivity analysis. J Volcanol Geotherm Res. 2015;296:80-100. https://doi. org/10.1016/j.jvolgeores.2015.03.009.

Brown C. Waste management following earthquake disaster. In: Beer M, Kougioumtzoglou IA, Patelli E, Au SK, editors. Encyclopedia of earthquake engineering. Berlin: Springer; 2014. https://doi.org/10.1007/ 978-3-642-36197-5_359-1.

Brown C, Milke M, Seville E. Disaster waste management: A review article. Waste Management. 2011;31(6):1085-98.

Chung C-JF, Fabrri AG. Validation of spatial prediction models for landslide hazard mapping. Nat Hazards. 2003;30(3):451-72. https://doi.org/10.1023/B: NHAZ.0000007172.62651.2b.

Climate-Data.org (2019) Los Lagos climate: average temperature, weather by month, Los Lagos weather averages. https://en.climate-data.org/southamerica/chile/xiv-region-de-los-rios/los-lagos-147327/. Accessed 29 May 2019.

Collins B, Dunne T, Lehre A. Erosion of tephra-covered hillslopes north of Mount St. Helens, Washington: May 1980-May 1981. Zeitschrift für Geomorphologische Naturwissenschaftliche Forschung. 1983;16:103-21.

Collins BD, Dunne T. Erosion of tephra from the 1980 eruption of Mount St. Helens. Geol Soc Am Bull. 1986;97:896-0. https://doi.org/10.1130/0016-7606 (1986) $97<896$ :eotfte>2.0.co;2.

Craig H, Wilson T, Stewart C, Outes V, Villarosa G, Baxter P. Impacts to agriculture and critical infrastructure in Argentina after ashfall from the 2011 eruption of the Cordón Caulle volcanic complex: an assessment of published damage and function thresholds. J Appl Volcanol. 2016;5:7. https:/doi.org/10.1186/s13617-016-0046-1.

Crawford MH, Crowley K, Potter SH, Saunders WSA, Johnston DM. Risk modelling as a tool to support natural hazard risk management in New Zealand local government. Int J Disaster Risk Reduct. 2018;28:610-9. https://doi.org/10.1 016/j.ijdrr.2018.01.011.

Deligne NI, Fitzgerald RH, Blake DM, Davies AJ, Hayes JL, Stewart C, Wilson G, Wilson TM, Castelino R, Kennedy BM, Muspratt S, Woods R. Investigating the consequences of urban volcanism using a scenario approach I: development and application of a hypothetical eruption in the Auckland volcanic field, New Zealand. J Volcanol Geotherm Res. 2017a;336:192-208. https://doi.org/1 0.1016/j.jvolgeores.2017.02.023.

Deligne NI, Horspool N, Canessa S, Matcham I, Williams GT, Wilson G, Wilson TM. Evaluating the impacts of volcanic eruptions using RiskScape. J Appl Volcanol. 2017b;6:18. https://doi.org/10.1186/s13617-017-0069-2.

Deligne NI, Jolly GE, Taig T, Webb TH. Evaluating life-safety risk for fieldwork on active volcanoes: the volcano life risk estimator (VoLREst), a volcano observatory's decision-support tool. J Appl Volcanol. 2018;7:7. https://doi. org/10.1186/s13617-018-0076-y.

Dominey-Howes D, Papathoma M. Validating a tsunami vulnerability model (the PTVA model) using field data from the 2004 Indian Ocean tsunami. Nat Hazards. 2007;40(1):113-36. https://doi.org/10.1007/s11069-006-0007-9.

Durand M, Gordon K, Johnston DM, Lorden R, Poirot T, Scott J, Shephard B. Impacts of, and responses to ashfall in Kagoshima from Sakurajima volcano: lessons for New Zealand. Lower Hutt: Institute of Geological \& Nuclear Sciences; 2001. Institute of Geological \& Nuclear Sciences science report 2001/30 53 p

Elissondo M, Baumann V, Bonadonna C, Pistolesi M, Cioni R, Bertagnini A, Biass S, Herrero J-C, Gonzalez R. Chronology and impact of the 2011 Cordón Caulle eruption, Chile. Nat Hazards Earth Syst Sci. 2016;16:675-704. https://doi.org/1 0.5194/nhess-16-675-2016.

Engwell SL, Sparks RSJ, Aspinall WP. Quantifying uncertainties in the measurement of tephra fall thickness. J Appl Volcanol. 2013;2:5. https://doi. org/10.1186/2191-5040-2-5.

FEMA (2007) Public assistance debris management guide. https://www.fema.gov/ media-library-data/20130726-1826-25045-7418/fema_325_debris_ management_guide_2007.07.25.pdf. Accessed 1 July 2019 .

FEMA. Multi-hazard loss estimation methodology earthquake model Hazus ${ }^{\oplus}-\mathrm{MH}$ 2.1 technical manual. Washington: Department of Homeland Security; $2013 \mathrm{a}$.

FEMA. Multi-hazard loss estimation methodology hurricane model Hazus ${ }^{\oplus}-\mathrm{MH} 2$. 1 technical manual. Washington: Department of Homeland Security; $2013 \mathrm{~b}$.

FEMA. Multi-hazard loss estimation methodology flood model Hazus ${ }^{\oplus}-\mathrm{MH}$ technical manual. Washington: Department of Homeland Security; 2013c.

Fisher EM, Noti JD, Lindsay WG, Blachere FM, Shaffer RE. Validation and application of models to predict facemask influenza contamination in healthcare settings. Risk Anal. 2014;34(8):1423-34. https://doi.org/10.1111/risa.12185.

Forte P, Dominguez L, Bonadonna C, Gregg CE, Bran D, Bird D, Castro JM. Ash resuspension related to the 2011-2012 Cordón Caulle eruption, Chile, in a rural community of Patagonia, Argentina. J Volcanol Geotherm Res. 2018;350: 18-32. https://doi.org/10.1016/j.jvolgeores.2017.11.021.

García-Torres S, Kahhat R, Santa-Cruz S. Methodology to characterize and quantify debris generation in residential buildings after seismic events. Resour Conserv Recycl. 2017;117:151-9. https://doi.org/10.1016/j.resconrec.2016.11.006.

Gobierno de la Provincia del Neuquen (2015a) Volcán Calbuco: ya se retiraron 18 mil metros cúbicos de cenizas en Junín y San Martín de los Andes. http:// www.neuqueninforma.gob.ar/volcan-calbuco-ya-se-retiraron-18-mil-metroscubicos-de-cenizas-en-junin-y-san-martin-de-los-andes/. Accessed 5 Jan 2018.

Gobierno de la Provincia del Neuquen (2015b) Continúan tareas de remoción en la zona afectada por la erupción del Calbuco. http://www.neuqueninforma. gob.ar/coordinan-tareas-de-remocion-en-la-zona-afectada-por-la-erupciondel-calbuco/. Accessed 5 Jan 2018.

Gobierno de la Provincia del Neuquen (2015c) Volcán Calbuco: siguen retirando cenizas en Junín y San Martín de los Andes. http://www.neuqueninforma. gob.ar/volcan-calbuco-siguen-retirando-cenizas-en-junin-y-san-martin-de-losandes/. Accessed 5 Jan 2018.

Gobierno de la Provincia del Neuquen (2015d) Junín de los Andes estará limpio de cenizas para fines de este mes. http://www.neuqueninforma. gob.ar/junin-de-los-andes-estara-limpio-de-cenizas-para-fines-de-este-mes/. Accessed 5 Jan 2018.

Gran KB, Montgomery DR, Halbur JC. Long-term elevated post-eruption sedimentation at Mount Pinatubo, Philippines. Geology. 2011;39(4):367-70. https://doi.org/10.1130/G31682.1.

GVM. In: Venzke E, editor. Calbuco (358020) in volcanoes of the world, v. 4.6.5: Smithsonian Institution; 2013. https://doi.org/10.5479/si.GVP.VOTW4-2013. http://volcano.si.edu/volcano.cfm?vn=358020. Accessed 3 Feb 2018. 
Hayes J, Wilson TM, Deligne NI, Cole J, Hughes M. A model to assess tephra clean-up requirements in urban environments. J Appl Volcanol. 2017;6:1. https://doi.org/10.1186/s13617-016-0052-3.

Hayes JL, Calderon R, Deligne NI, Jenkins SF, Leonard GS, McSporran A, Williams GT, Wilson TM. Timber-framed building damage from tephra fall and lahar: 2015 Calbuco eruption, Chile. J Volcanol Geotherm Res. 2019b;374:142-59. https://doi.org/10.1016/j.jvolgeores.2019.02.017.

Hayes JL, Deligne NI, Bertin L, Calderon R, Wardman J, Wilson TM, Leonard GS, Stewart C, Wallace KL, Baxter P. Impacts of the 2015 eruption of Calbuco volcano on Chilean infrastructure, utilities, agriculture, and health; 2019a. https://doi.org/10.21420/02YC-VX66. GNS Science report 2019/04

Hayes JL, Wilson TM, Magill C. Tephra fall clean-up in urban environments. J Volcanol Geotherm Res. 2015;304:359-77. https://doi.org/10.1016/j. jvolgeores.2015.09.014.

Hildreth W, Drake RE. Volcán Quizapu, Chilean Andes. Bull Volcanol. 1992;54(2): 93-125. https://doi.org/10.1007/BF00278002.

Horwell CJ, Baxter PJ. The respiratory health hazards of volcanic ash: a review for volcanic risk mitigation. Bull Volcanol. 2006;69(1):1-24. https://doi.org/10.1 007/s00445-006-0052-y.

Jenkins SF, Spence RJS, Fonesca JFBD, Solidum RU, Wilson TM. Volcanic risk assessment: quantifying physical vulnerability in the built environment. J Volcanol Geotherm Res. 2014;276:105-20. https://doi.org/10.1016/j. jvolgeores.2014.03.002.

Johnston DM, Becker J, Alloway B, Manville V (2001) Auckland engineering lifelines group volcanic ash review part 1, impacts on lifeline services and collection/disposal issues. Auckland Regional Council Technical Publication No.144.

Lavigne F, Thouret J-C. Sediment transportation and deposition by rain-triggered lahars at Merapi volcano, Central Java, Indonesia. Geomorphology. 2003; 49(1-2):45-69. https://doi.org/10.1016/S0169-555X(02)00160-5.

Le Pennec J-L, Ruiz GA, Ramón P, Palacios E, Mothes P, Yepes H. Impact of tephra falls on Andean communities: the influences of eruption size and weather conditions during the 1999-2001 activity of Tungurahua volcano, Ecuador. J Volcanol Geotherm Res. 2012;217-218:91-103. https://doi.org/10.1016/j. jvolgeores.2011.06.011.

Lecointre J, Hodgson K, Neall, Cronin S. Lahar-triggering mechanisms and hazard at Ruapehu volcano, New Zealand. Nat Hazards. 2004;31(1):85-109. https:// doi.org/10.1023/B:NHAZ.0000020256.16645.eb.

Lirer L, Vitelli L. Volcanic risk assessment and mapping in the Vesuvian area using GIS. Nat Hazards. 1998;17(1):1-15. https://doi.org/10.1023/A:1007977110144.

Liu EJ, Cashman KV, Beckett FM, Witham CS, Leadbetter SJ, Hort MC, Guðmundsson S. Ash mists and brown snow: remobilization of volcanic ash from recent Icelandic eruptions. J Geophys Res Atmos. 2014;119(15):9463-80. https://doi.org/10.1002/2014JD021598.

Loughlin S, Sparks S, Brown SK, Jenkins SF, Vye-Brown C. Global volcanic hazards and risk: Cambridge University Press; 2015. https://doi.org/10.1017/ CBO9781316276273.

Magill C, Blong R. Volcanic risk ranking for Auckland, New Zealand. II: Hazard consequences and risk calculation. Bull Volcanol. 2005;67(4):340-9. https:// doi.org/10.1007/s00445-004-0375-5.

Magill C, Blong R, McAneney J. VolcaNZ—A volcanic loss model for Auckland, New Zealand. Journal of Volcanology and Geothermal Research. 2006;149(34):329-345.

Magill C, Wilson T, Okada T. Observations of tephra fall impacts from the 2011 Shinmoedake eruption, Japan. Earth Planets Space. 2013;65:18. https://doi. org/10.5047/eps.2013.05.010

Major JJ, Pierson TC, Dinehart RL, Costa JE. Sediment yield following severe volcanic disturbance-a two-decade perspective from Mount St. Helens. Geology. 2000;28(9):819-22. https://doi.org/10.1130/0091-7613(2000)28<819: SYFSVD>2.0.CO;2.

Maraş SS, Maraş HH, Yildiz BA, Maraş EE, Yildiz F. Topological error correction of GIS vector data. Int J Phys Sci. 2010;5(5):476-83.

Marzocchi W, Woo G. Principles of volcanic risk metrics: theory and the case study of Mount Vesuvius and Campi Flegrei, Italy. J Geophys Res Solid Earth. 2009;114(B3). https://doi.org/10.1029/2008JB005908.

McDonald GW, Smith NJ, Kim J, Cronin SJ, Proctor JN. The spatial and temporal 'cost' of volcanic eruptions: assessing economic impact, business inoperability, and spatial distribution of risk in the Auckland region, New Zealand. Bull Volcanol. 2017;79:48. https://doi.org/10.1007/s0044.

Ministerio del Interior (2018a). Villa La Angostura. http://www.mininterior.gov.ar/ municipios/masinfo.php?municipio=NEU046. Accessed 12 Nov 2018.
Ministerio del Interior (2018b). San Martín de Los Andes. http://www.mininterior. gov.ar/municipios/masinfo.php?municipio=NEU034. Accessed 12 Nov 2018

Ministerio del Interior (2018c). Junin de los Andes. http://www.mininterior.gov.ar/ municipios/masinfo.php?municipio=NEU017. Accessed 12 Nov 2018.

Murnane R, Simpson A, Jongman B. Understanding risk: what makes a risk assessment successful? Int J Disaster Resilience Built Environ. 2016;7(2):186299. https://doi.org/10.1108/IJDRBE-06-2015-0033.

Nateghi R, Guikema S, Quiring SM. Comparison and validation of statistical methods for predicting power outage durations in the event of hurricanes. Risk Anal. 2011;31(12):1897-906. https://doi.org/10.1111/j.1539-6924.2011.01618.x.

Newhall CG. A method for estimating intermediate and long- term risks from volcanic activity, with an example from Mount St. Helens, Washington. In: US Geol Surv Open-file Rep; 1982. p. 82-396.

Newhall CG, Self S. The volcanic explosivity index (VEI): an estimate of explosive magnitude for historical volcanism. J Geophys Res. 1982;87:1231-8. https:// doi.org/10.1029/jc087ic02p01231.

Peel MC, Finlayson BL, McMahon TA. Updated world map of the Köppen-Geiger climate classification. Hydrol Earth Syst Sci. 2007;11:1633-44. https://doi.org/1 0.5194/hess-11-1633-2007.

Reckziegel F, Bustos E, Mingari L, Báez W, Villarosa G, Folch A, Collini E, Viramonte J, Romero J, Osores S. Forecasting volcanic ash dispersal and coeval resuspension during the April-May 2015 Calbuco eruption. J Volcanol Geotherm Res. 2016; 321:44-57. https://doi.org/10.1016/j.jvolgeores.2016.04.033.

RioNegro (2015) Aeropuerto Chapelco recibiría vuelos desde el Viernes. https:// www.rionegro.com.ar/region/aeropuerto-chapelco-recibiria-vuelos-desde-elviernes-IPRN_7566192. Accessed 5 Jan 2018.

Romero JE, Morgavi D, Arzilli F, Daga R, Caselli A, Reckziegel F, Viramonte J, DíazAlvarado J, Palacci M, Burton M, Perugini D. Eruption dynamics of the 22-23 April 2015 Calbuco volcano (Southern Chile): analyses of tephra fall deposits. J Volcanol Geotherm Res. 2016;317:15-29. https://doi.org/10.1016/j.jvolgeores.2016.02.027.

San Martín Diario (2015) Volcán Calbuco: ya se retiraron 18 mil metros cúbicos de cenizas en Junín y San Martín de los Andes. http://www.sanmartinadiario. com/actualidad/10234-volcan-calbuco-ya-se-retiraron-18-mil-metros-cubicosde-cenizas-en-junin-y-san-martin-de-los-andes.html. Accessed 5 Jan 2018.

Sparks RSJ, Aspinall WP, Crosweller HS, Hincks TK. Risk and uncertainty assessment of volcanic hazards. In: Rougier JC, Sparks RSJ, Hill L, editors. Risk and uncertainty assessment in natural hazards: Cambridge University Press; 2013. p. 364 e397 (Chapter 11). https://doi.org/10.1017/cbo9781139047562.012.

Spence RJS, Kelman I, Baxter PJ, Zuccaro G, Petrazzuoli S. Residential building and occupant vulnerability to tephra fall. Nat Hazards Earth Syst Sci. 2005;5(4): 477-94. https://doi.org/10.5194/nhess-5-477-2005.

Sword-Daniels V, Wilson TM, Sargeant S, Rossetto T, Twigg J, Johnston DM, Loughlin SC, Cole PD. Chapter 26 consequences of long-term volcanic activity for essential services in Montserrat: challenges, adaptations and resilience. Geol Soc Lond Mem. 2014;39(1):471-88 http://mem.lyellcollection. org/content/39/1/471.abstract

Thorarinsson S (1954) The eruptions of Hekla 1947-1948. In: The tephra fall from Hekla. Vis Islendinga, Reykjavik, 3(2):68.

Tonkin \& Taylor (2018) New Zealand disaster waste management planning tool working copy June 2018. https://www.ecan.govt.nz/your-region/yourenvironment/waste-and-hazardous-substances/managing-disaster-waste/. Accessed 15 June 2019.

Valderrama O, Cardona C, Gil-Cruz F. Erupción sub-pliniana del Volcán Calbuco (Chile) Abril de 2015, un ejemplo de erupciones intempestivas con pocos premonitorios. [Sub-Plinian eruption of Calbuco volcano (Chile), April 2015, an example of untimely eruptions with few premonitory]. Puerto Vallarta: Congreso LAVAS IV; 2016.

Van Eaton AR, Amigo A, Bertin D, Mastin LG, Giacosa RE, González J, Valderrama O, Fontijn K, Behnke SA. Volcanic lightning and plume behavior reveal evolving hazards during the April 2015 eruption of Calbuco volcano, Chile. Geophys Res Lett. 2016;43(7):3563-71. https://doi. org/10.1016/10.1002/2016GL068076.

van Westen CJ, Daag AS. Analysing the relation between rainfall characteristics and lahar activity at Mount Pinatubo, Philippines. Earth Surf Process Landf. 2005:30(13):1663-74. https://doi.org/10.1002/esp.1225.

Villarosa G, Outes V, Delménico A, Beigt D, Cottet J. Impacts after the 2015 Calbuco eruption in Argentina and their relation to tephra deposit characteristics and climatic variables. Cities on Volcanoes 9. Puerto Varas: Cities on Volcanoes 9; 2016.

Wantim MN, Bonadonna C, Gregg CE, Menoni S, Frischknecht C, Kervyn M, Ayonghe SN. Forensic assessment of the 1999 Mount Cameroon eruption, West-Central Africa. J Volcanol Geotherm Res. 2018:358:13-30. https://doi. org/10.1016/j.jvolgeores.2018.06.007. 
Wardman J, Sword-Daniels V, Stewart C, Wilson T (2012) Impact assessment of the May 2010 eruption of Pacaya volcano, Guatemala. GNS Science Report 2012/09.

Watson CC Jr, Johnson ME. Hurricane loss estimation models: opportunities for improving the state of the art. Bull Am Meteorol Soc. 2004;85(11):1713-26. https://doi.org/10.1175/BAMS-85-11-1713.

Wilson G, Wilson TM, Deligne NI, Cole JW. Volcanic hazard impacts to critical infrastructure: a review. J Volcanol Geotherm Res. 2014;286:148-82. https:// doi.org/10.1016/j.jvolgeores.2014.08.030.

Wilson T, Stewart C, Bickerton H, Baxter P, Outes V, Villarosa G, Rovere E. Impacts of the June 2011 Puyehue-Cordón Caulle volcanic complex eruption on urban infrastructure, agriculture and public health. GNS Science Report 2012/ 20; 2013. p. 88.

Wilson TM, Cole JW, Stewart C, Cronin SJ, Johnston DM. Ash storms: impacts of wind-remobilised volcanic ash on rural communities and agriculture following the 1991 Hudson eruption, southern Patagonia, Chile. Bull Volcanol. 2011;73(3):223-39. https://doi.org/10.1007/s00445-010-0396-1.

Wilson TM, Stewart C, Sword-Daniels V, Leonard GS, Johnston DM, Cole JW, Wardman J, Wilson G, Barnard ST. Volcanic ash impacts on critical infrastructure. Phys Chem Earth Parts ABC. 2012;45-46:5-23. https://doi.org/1 0.1016/j.pce.2011.06.006.

Woo G. Probabilistic criteria for volcano evacuation decisions. Nat Hazards. 2008; 45(1):87-97. https://doi.org/10.1007/s11069-007-9171-9.

Zerger A. Examining GIS decision utility for natural hazard risk modelling. Environ Model Softw. 2002;17(3):287-94. https://doi.org/10.1016/S13648152(01)00071-8

Zuccaro G, Cacace F, Spence RJS, Baxter PJ. Impact of explosive eruption scenarios at Vesuvius. Journal of Volcanology and Geothermal Research. 2008;178(3):416-53.

Zuccaro G, Leone MT, Cogliano DD, Sgroi A. Economic impact of explosive volcanic eruptions: a simulation-based assessment model applied to Campania region volcanoes. J Volcanol Geotherm Res. 2013;266:1-15. https:// doi.org/10.1016/j.jvolgeores.2013.09.002.

\section{Publisher's Note}

Springer Nature remains neutral with regard to jurisdictional claims in published maps and institutional affiliations.

Ready to submit your research? Choose BMC and benefit from:

- fast, convenient online submission

- thorough peer review by experienced researchers in your field

- rapid publication on acceptance

- support for research data, including large and complex data types

- gold Open Access which fosters wider collaboration and increased citations

- maximum visibility for your research: over $100 \mathrm{M}$ website views per year

At $\mathrm{BMC}$, research is always in progress.

Learn more biomedcentral.com/submissions 